\title{
An Early Block in the Replication of the Atypical Bluetongue Virus Serotype 26 in Culicoides Cells Is Determined by Its Capsid Proteins
}

\author{
Marc Guimerà Busquets ${ }^{1, *}$, Gillian D. Pullinger ${ }^{1}$, Karin E. Darpel ${ }^{1}$, Lyndsay Cooke ${ }^{1}{ }^{\circledR}$, Stuart Armstrong ${ }^{2}$, \\ Jennifer Simpson ${ }^{1}$, Massimo Palmarini ${ }^{3}$, Rennos Fragkoudis ${ }^{4}$ and Peter P. C. Mertens ${ }^{5}$ \\ 1 The Pirbright Institute, Pirbright, Surrey GU24 0NF, UK; gillian.pullinger@btinternet.com (G.D.P.); \\ karin.darpel@pirbright.ac.uk (K.E.D.); lyndsayscooke@outlook.com (L.C.); \\ jennifer.simpson@pirbright.ac.uk (J.S.) \\ 2 Institute of Infection and Global Health, University of Liverpool, Liverpool Science Park IC2, \\ Liverpool L3 5RF, UK; sarmstro@liverpool.ac.uk \\ 3 MRC-University of Glasgow Centre for Virus Research, Sir Michael Stoker Building, Garscube Campus, \\ University of Glasgow, Glasgow G61 1QH, UK; Massimo.Palmarini@glasgow.ac.uk \\ 4 Edinburgh Genome Foundry, University of Edinburgh, Edinburgh EH9 3BF, UK; R.Fragkoudis@ed.ac.uk \\ 5 School of Veterinary Medicine and Science, University of Nottingham, Sutton Bonington Campus, \\ Nottingham LE12 5RD, UK; Peter.Mertens@nottingham.ac.uk \\ * Correspondence: Marc.GuimeraBusquets@pirbright.ac.uk
}

Citation: Guimerà Busquets, M.; Pullinger, G.D.; Darpel, K.E.; Cooke, L.; Armstrong, S.; Simpson, J.; Palmarini, M.; Fragkoudis, R.; Mertens, P.P.C. An Early Block in the Replication of the Atypical

Bluetongue Virus Serotype 26 in Culicoides Cells Is Determined by Its Capsid Proteins. Viruses 2021, 13, 919. https://doi.org/10.3390/v13050919

Academic Editors: Noemí Sevilla, Verónica Martín and José M. Rojas

Received: 25 March 2021

Accepted: 7 May 2021

Published: 15 May 2021

Publisher's Note: MDPI stays neutral with regard to jurisdictional claims in published maps and institutional affiliations.

Copyright: (c) 2021 by the authors. Licensee MDPI, Basel, Switzerland. This article is an open access article distributed under the terms and conditions of the Creative Commons Attribution (CC BY) license (https:// creativecommons.org/licenses/by/ $4.0 /)$.

\begin{abstract}
Arboviruses such as bluetongue virus (BTV) replicate in arthropod vectors involved in their transmission between susceptible vertebrate-hosts. The "classical" BTV strains infect and replicate effectively in cells of their insect-vectors (Culicoides biting-midges), as well as in those of their mammalian-hosts (ruminants). However, in the last decade, some "atypical" BTV strains, belonging to additional serotypes (e.g., BTV-26), have been found to replicate efficiently only in mammalian cells, while their replication is severely restricted in Culicoides cells. Importantly, there is evidence that these atypical BTV are transmitted by direct-contact between their mammalian hosts. Here, the viral determinants and mechanisms restricting viral replication in Culicoides were investigated using a classical BTV-1, an "atypical" BTV-26 and a BTV-1/BTV-26 reassortant virus, derived by reverse genetics. Viruses containing the capsid of BTV-26 showed a reduced ability to attach to Culicoides cells, blocking early steps of the replication cycle, while attachment and replication in mammalian cells was not restricted. The replication of BTV-26 was also severely reduced in other arthropod cells, derived from mosquitoes or ticks. The data presented identifies mechanisms and potential barriers to infection and transmission by the newly emerged "atypical" BTV strains in Culicoides.
\end{abstract}

Keywords: arbovirus; bluetongue; BTV-26; atypical serotype; reverse genetics; cell binding; VP2

\section{Introduction}

Bluetongue virus (BTV) is the causative agent of 'bluetongue' (BT), a haemorrhagic disease of domesticated and wild ruminants, although camelids and certain species of large carnivores can also become infected [1-3]. Bluetongue is of high economic importance to the agriculture sector, causing fatalities and production losses in livestock, and is notifiable to the World Organization for Animal Health (OIE) [4].

Bluetongue virus is the type species of the genus Orbivirus, family Reoviridae. It has an icosahedral capsid, approximately $80 \mathrm{~nm}$ in diameter, composed of three concentric layers of proteins [5,6]. Twenty-four distinct BTV serotypes (BTV-1 to BTV-24) have been recognised for many decades, the identity of which is determined by the specificity of neutralising antibody interactions with their outer-capsid protein VP2 [7]. These 'classical' BTV strains are arthropod-borne viruses (arboviruses), transmitted between their ruminant hosts primarily by adult Culicoides biting-midges (Diptera: Ceratopogonidae), although more 
rarely, transmission can also occur via transplacental transmission, or ingestion of infected material [8-10].

BTV infects and replicates in its insect vectors, after ingestion as part of a blood meal from an infected vertebrate host, resulting in internal dissemination and infection of the insect salivary glands. This allows the virus to be transmitted to other hosts through the insect's saliva during subsequent blood meals. Consequently, the incidence of BTV infections is directly linked to the global and seasonal distribution of vector-competent, adult Culicoides populations. Currently, 1357 species of Culicoides have been described [11], of which at least 13 different species have been implicated as BTV vectors (reviewed in [12]).

The geographic spread of BT outbreaks has recently expanded northwards, beyond their historical distribution (between latitudes $40^{\circ} \mathrm{S}$ and $53^{\circ} \mathrm{N}$ ), with the virus becoming endemic in southern and central Europe $[13,14]$. These changes have been linked to increased travel/trade and particularly the effects of climate change on the distribution and seasonal activity of vector species/populations in the region.

Since 2008 several BTV strains have emerged that belong to previously unrecognized serotypes, (including BTV-25, 26 and 27), as well as strains that have not yet been assigned to specific serotypes $[15,16]$. Some of these novel viruses are adapted to small ruminants (sheep and goats), causing asymptomatic infections, but are unable to replicate effectively in adult Culicoides sonorensis, or in KC cells [17-20]. These atypical strains are believed to be transmitted primarily by direct animal to animal contact $[18,20,21]$.

The ability of an arthropod vector to become infected and subsequently transmit the virus to a susceptible host determines its vector competence. This ability varies between Culicoides species, and different levels of susceptibility to BTV infection are also observed between individual insects of the same species, as well as between different strains of BTV [22-25]. This indicates that host, virus and vector characteristics (genetic factors), as well as different environmental variables can all be involved in determination of transmission efficiency, vector competence of individual insects and the overall vector capacity of vector populations [26,27]. Some aspects of Culicoides-dependent vector-competence have been studied (reviewed in [28]) and the role played by several of the viral proteins in the replication of BTV in Culicoides cells has been shown in vitro and in vivo [19,29]. However, in general, the determinants that control vector competence and the mechanisms involved are poorly understood.

The genome of BTV comprises ten linear segments of double stranded (ds) RNA, identified as segment 1 to 10 (Seg-1 to Seg-10) in order of decreasing molecular weight [6], which collectively encode seven structural proteins (VP1 to VP7), and at least four nonstructural proteins (NS1 to NS4), plus a putative NS5 protein encoded by an additional ORF in segment 10 [30-32]. Within the particle, each of the ten packaged dsRNA segments is associated with a transcriptase complex (TC) that consist of an RNA-dependent RNA polymerase (VP1/Seg-1), a helicase (VP6/Seg-9) and a capping enzyme (VP4/Seg4) $[5,33,34]$. The innermost capsid shell ('sub-core'), which surrounds and interacts with both the genome segments and TCs, is composed of 120 copies of VP3 (encoded by Seg-3). The intermediate 'core surface' layer contains 260 trimers of VP7 (encoded by Seg-7), which interact with both the outer-capsid and the sub-core. The external 'outer-capsid' layer is assembled from 60 trimers of VP2 (encoded by Seg-2) and 120 trimers of VP5 (encoded by Seg-6).

In mammalian cells, the BTV outer-capsid is responsible for cell attachment, via the interaction of VP2 and a still unknown receptor(s) on the cell surface, followed by internalization/cell-membrane penetration mediated by VP5 [35-38]. The mechanisms by which BTV initiates infection of Culicoides cells have been studied to a much lesser extent than in mammalian cells. In addition to intact BTV virus-particles, particles with protease-cleaved VP2 (infectious sub-viral particles-ISVP) and core particles that have lost their outer capsid components, can also be highly infectious for the $\mathrm{KC}$ cell line (derived from C. sonorensis) and for adult Culicoides via an oral route [39,40]. This suggests the 
use of multiple cell-attachment and entry mechanisms, involving VP2/VP5 or VP7, also potentially utilizing different cell-surface receptors.

VP2 and to a lesser extent VP5, are the most variable of the BTV proteins [7]. The amino-acid/nucleotide sequences of VP2/Seg-2 can be divided into distinct phylogenetic clades, which correlate with BTV serotype [7]. To date, at least 27 distinct serotypes have been recognized, which include the novel, 'atypical' BTV strains of BTV-25, -26 and $-27[17,41,42]$. Several additional putative novel BTV serotypes have also recently been identified $[15,43,44]$.

The ability of BTV-26 from Kuwait (isolate KUW2010/02) to replicate efficiently in mammalian cells (for example BSR cells), but not in Culicoides cells, provides an opportunity to study BTV-vector interactions. Reassortant viruses generated by reverse genetics, containing a selection of genome-segments from BTV-26 and the reference strain of BTV-1, were generated and used in our previous study to identify four genome segments of BTV-26 that completely (Seg-1, encoding VP1-RNA-dependent-RNA-polymerase; Seg-2, encoding VP2-outer-capsid protein; and Seg-3, encoding VP3-sub-core shell protein); or partially (Seg-7, encoding VP7-outer-core protein) restrict replication in vitro in Culicoides derived KC cells [19], while maintaining complete ability to infect and replicate in a mammalian BSR cell line. Here we build on our previous work to initially investigate the ability of BTV-26 to replicate in cells derived from other 'potential' arthropod-vectors, including both mosquitoes and ticks as well as bovine host derived endothelial cells.

As cell binding and entry is a key factor in restricting virus host-cell range we, furthermore, specifically investigate the role of the outer capsid proteins of BTV-26 in preventing infection of Culicoides-derived cells and adult vector Culicoides. We report binding and replication studies using BTV-26 and a reassortment virus based on BTV-1, but containing capsid proteins VP2, VP5 and VP7 of BTV-26, and identify that early stages of the BTV-26 replication cycle, including cell-attachment, are impeded in KC cells, but not in mammalianderived cells. This block cannot be overcome by higher MOIs or temperatures. Like the BTV-26 wild-type, the reassortant virus is also incapable of replicating to transmissible levels in adult female $C$. sonorensis midges, confirming that the capsid of BTV-26 is defective in infecting midges, and greatly contributes to the overall inability of BTV-26 to efficiently replicate and 'amplify' in Culicoides-derived cells or adult midges.

\section{Materials and Methods}

\subsection{Viruses and Cells}

The viruses used in this study were obtained from the dsRNA virus collection at The Pirbright Institute (TPI) (Table 1). A 'reverse engineered' virus (rBTV-1) was generated in BSR cells (a clone of baby hamster kidney cells BHK-21 [45], and obtained from Dr Mark Boyce, The Pirbright Institute, Woking, UK), as already described [19], using mRNAs derived from the reference strain for BTV serotype 1 (BTV-1, isolate (RSArrrr/01), originally from South Africa). The reference strain for BTV-26 (KUW2010/02), (referred to as BTV-26), was isolated from ovine blood samples from Kuwait [41]. The strain, $\mathrm{rBTV} 1_{26 \mathrm{~S} 2, \mathrm{~S} 6, \mathrm{~S} 7}$ was 'reverse engineered' containing genome-segments 2, 6 and 7 (Seg-2, 6 and 7) from BTV-26 (coding for the larger outer-capsid protein VP2, the smaller outer-capsid protein VP5 and core-surface protein VP7 respectively), with the remaining genome-segments (the genetic 'backbone') from BTV-1 RSArrrr/01 [19] (Table 1). Virus stocks were generated in BSR cells.

Mammalian BSR and BFA cells (Bovine Foetal Aorta endothelium cells, catalogue number 87022601, European Collection of Authenticated Cell Cultures, Public Health England, Porton Down, Salisbury, UK) were incubated at $+37^{\circ} \mathrm{C}$ with $5 \% \mathrm{CO}_{2}$. BSR cells were grown in Dulbecco's modified Eagle medium (DMEM) GlutaMAX (Gibco ${ }^{\circledR}$ by Life Technologies Limited, Paisley, UK) with 5\% heat-inactivated foetal bovine serum (HI-FBS) (Gibco ${ }^{\circledR}$ by Life Technologies Limited, Paisley, UK) and penicillin (100 U/mL)/streptomycin $(100 \mu \mathrm{g} / \mathrm{mL})\left(1 \%\right.$ Pen/Strep) (Gibco ${ }^{\circledR}$ by Life Technologies Limited, Paisley, UK). BFA cells were grown in Nutrient Mixture F-12 Ham's medium (Sigma-Aldrich ${ }^{\circledR}$, Gillingham, UK) with $10 \%$ HI-FBS and $1 \%$ Pen/Strep. 
Table 1. List of viruses.

\begin{tabular}{|c|c|c|c|}
\hline $\begin{array}{l}\text { Virus } \\
\text { (ORC number) }^{1}\end{array}$ & Cell Passage History ${ }^{2}$ & Origin $^{3}$ & Comments \\
\hline BTV-1 (RSArrrr/01) & E2, BHK9, BSR1 * & Natural (TPI) & Strain used for segment cloning, identified as wtBTV-1 \\
\hline BTV-26 (KUW2010/02) & E1, BHK2, BSR1 & Natural (TPI) & $\begin{array}{l}\text { Strain used for segment cloning and infections, identified } \\
\text { as BTV-26 }\end{array}$ \\
\hline rBTV-1 (BTV-RV0023) & BSR3 & Synthetic & $\begin{array}{l}\text { Rescued strain, derived from BTV-1 RSArrrr/01 } \\
\text { cloned segments }\end{array}$ \\
\hline rBTV-1 26 S2,S6,S7 (BTV-RV0020) & BSR3 & Synthetic & $\begin{array}{l}\text { Rescued strain comprised of wtBTV- } 1 \text { derived backbone, } \\
\text { with genome-segments 2, } 6 \text { and } 7 \text { derived from BTV-26 }\end{array}$ \\
\hline
\end{tabular}

KC cells, originally derived from 2-day-old Culicoides sonorensis midge embryos [46] (cell line maintained at the Pirbright Institute, Woking, UK, and originally provided by Sally Wechsler, USDA Laramie, Laramie, WY, USA [39]), and U4.4 cells (derived from Aedes albopictus mosquito larvae [47], obtained from Dr Sue Jacobs, TPI, Woking, UK) were incubated at $+28{ }^{\circ} \mathrm{C}$ without $\mathrm{CO}_{2}$. KC cells were grown in Schneider's insect medium (Sigma-Aldrich ${ }^{\circledR}$, Gillingham, UK) with 10\% HI-FBS and 1\% Pen/Strep. U4.4 cells were maintained with Leibowitz's L-15 medium GlutaMAX ${ }^{\mathrm{TM}}$ (Gibco ${ }^{\circledR}$ by Life Technologies Limited, Paisley, UK) with 10\% HI-FBS, 2\% Tryptose Phosphate Broth (TPB) (SigmaAldrich $^{\circledR}$, Gillingham, UK) and $1 \%$ Pen/Strep.

Tick cells lines RAE25 (derived from Rhipicephalus appendiculatus tick embryos [48]) and HAE/CTVM9 (derived from Hyalomma anatolicum tick embryos [49]) were incubated at $+32{ }^{\circ} \mathrm{C}$ without $\mathrm{CO}_{2}$. RAE25 were maintained and provided ready to infect by Dr Lesley Bell-Sakyi, University of Liverpool, Liverpool, UK.

\subsection{Time-Course Experiments}

Replication kinetics experiments were carried out in mammalian, insect and tick cell lines. Except for the tick cells, these experiments were carried out in $T 25 \mathrm{~cm}^{2}$ flasks or 24-well plates (Corning ${ }^{\circledR}$ Costar $^{\circledR}$, Corning Inc., Corning, NY, USA). Cells were seeded and incubated at their corresponding temperature overnight (Table 2). The following day, cells were infected with BTV diluted in serum-free medium at a multiplicity of infection (MOI) of $0.01,1$, or 5, depending on the experiment. Virus was allowed to adsorb at room temperature for one hour. The inoculum was then removed, and cells washed three times with Dulbecco's phosphate buffered saline (DPBS) calcium and magnesium free (Sigma-Aldrich ${ }^{\circledR}$, Gillingham, UK). Six mL (for T25 $\mathrm{cm}^{2}$ ) or $1 \mathrm{~mL}$ (for 24-well plate) of fresh maintenance medium (Table 2) was added in each flask/well. Supernatant samples $(250 \mu \mathrm{L})$ and/or coverslips were immediately collected, at 0 days post infection $(0 \mathrm{dpi})$. For infections carried out in $\mathrm{T} 25 \mathrm{~cm}^{2}$ flasks, $250 \mu \mathrm{L}$ of fresh 'replacement' medium was added. For infections carried out in 24-well plates, one well was used per time point, and cells were then incubated at appropriate temperatures (Table 2). Supernatant samples were collected at selected times pi and stored at $+4^{\circ} \mathrm{C}$ until the end of the experiment, when RNA was extracted from $100 \mu$ l of each sample using a Kingfisher ${ }^{\mathrm{TM}}$ Flex robot (Thermo Fisher Scientific, Swindon, UK) and the LSI MagVet ${ }^{\mathrm{TM}}$ Universal Isolation Kit (Thermo Fisher Scientific, Swindon, UK) as per manufacturer's instructions. Virus copy numbers were quantified using a BTV qRT-PCR assay targeting genome-segment 9 [50], with a 10-fold serial dilution of Seg-9 RNA in vitro transcripts as standard. Coverslips were fixed for $1 \mathrm{~h}$ in $4 \%$ paraformaldehyde (Santa Cruz Biotechnology, Inc., Dallas, TX, USA) immediately after collection and kept in PBS at $+4{ }^{\circ} \mathrm{C}$ until processed for immunofluorescence staining. 
Table 2. Cell culture conditions during virus infection.

\begin{tabular}{|c|c|c|c|}
\hline Cell Line & No. of Seeded Cells & Incubation $\left({ }^{\circ} \mathrm{C}\right)$ & Maintenance Medium \\
\hline BSR & $\begin{array}{l}1 \times 10^{5} \text { cells } / \text { well }(24 \text { well plate) } \\
3 \times 10^{6} \text { cells } / \text { flask (T25 cm² flask) }\end{array}$ & $\begin{array}{l}37 \pm 1 \\
\text { with } 5 \% \mathrm{CO}_{2}\end{array}$ & DMEM GlutaMAX ${ }^{\mathrm{TM}}+1 \%$ HI-FBS + 1\% Pen/Strep \\
\hline BFA & $1 \times 10^{5}$ cells $/$ well ( 24 well plate) & $\begin{array}{l}37 \pm 1 \\
\text { with } 5 \% \mathrm{CO}_{2}\end{array}$ & $\begin{array}{l}\text { Nutrient Mixture F-12 Ham's medium }+1 \% \text { HI-FBS }+ \\
1 \% \text { Pen/Strep }\end{array}$ \\
\hline $\mathrm{KC}$ & $\begin{array}{l}7 \times 10^{5} \text { cells/well ( } 24 \text { well plate) } \\
2.5 \times 10^{7} \text { cells/flask (T25 cm² flask) }\end{array}$ & $\begin{array}{l}27 \pm 1 \\
\text { without } \mathrm{CO}_{2}\end{array}$ & $\begin{array}{l}\text { Schneider's insect medium + 10\% HI-FBS }+1 \% \\
\text { Pen/Strep }\end{array}$ \\
\hline U4.4 & $2.5 \times 10^{7}$ cells $/$ flask $\left(\mathrm{T} 25 \mathrm{~cm}^{2}\right.$ flask) & $\begin{array}{l}27 \pm 1 \\
\text { without } \mathrm{CO}_{2}\end{array}$ & $\begin{array}{l}\text { Leibowitz's L-15 GlutaMAX }{ }^{\mathrm{TM}}+10 \% \text { HI-FBS }+2 \% \\
\text { TPB }+1 \% \text { Pen/Strep }\end{array}$ \\
\hline RAE25 & $2.4 \times 10^{6}$ cells $/$ tube $\left(5.5 \mathrm{~cm}^{2}\right.$ flat-sided tubes $)$ & $\begin{array}{l}32 \pm 1 \\
\text { without } \mathrm{CO}_{2}\end{array}$ & L-15 GlutaMAX ${ }^{\mathrm{TM}}+10 \%$ HI-FBS + 5\% TPB \\
\hline HAE/CTVM9 & $2.4 \times 10^{6}$ cells $/$ tube $\left(5.5 \mathrm{~cm}^{2}\right.$ flat-sided tubes $)$ & $\begin{array}{l}32 \pm 1 \\
\text { without } \mathrm{CO}_{2}\end{array}$ & L-15/H-Lac + 20\% HI-FBS \\
\hline
\end{tabular}

For characterization of virus replication in tick-derived cells, the cells were seeded in $5.5 \mathrm{~cm}^{2}$ flat-sided tubes (Nunc ${ }^{\mathrm{TM}}$, Thermo Fisher Scientific, Swindon, UK) (Table 2) and infected at a MOI of 1. Virus inoculum was left to adsorb at room temperature for $90 \mathrm{~min}$ and then removed. Cells were washed twice with PBS and $1.5 \mathrm{~mL}$ of fresh maintenance medium was added (Table 2). Supernatant samples $(250 \mu \mathrm{L})$ were collected immediately (0 dpi sample) from each tube and fresh replacement medium was added $(250 \mu \mathrm{L})$. Tubes were then incubated at $+32{ }^{\circ} \mathrm{C}$ without $\mathrm{CO}_{2}$ for thirty days. Supernatant samples $(250 \mu \mathrm{L})$ were collected daily during the first 10 days and subsequently every five or ten days, up to thirty days pi. Medium was replaced $(250 \mu \mathrm{L})$ after each sampling. To maintain cell viability, two-thirds of the medium was changed every 10 days. When a medium change was carried out, a sample was collected before and after the medium change. All samples were stored at $+4{ }^{\circ} \mathrm{C}$ until the end of the experiment, when viral RNA was extracted, and viral genome copies were quantified (as above).

\subsection{Virus Titration}

End-point titration of virus stocks or selected supernatants were carried out on BSR cells in 96 well tissue culture plates. Briefly, $100 \mu \mathrm{L}$ of BSR cells in DMEM containing 1\% FBS (HI) at a density of $3 \times 10^{5}$ cells $/ \mathrm{mL}$ was added to each well. In a separate 96 deep-well plate, a 10-fold serial dilution (from $10^{-1}$ to $10^{-8}$ ) of the virus sample to be titrated was made in DMEM $/ 1 \%$ FBS (HI) $/ 1 \%$ Pen/Strep. $100 \mu \mathrm{L}$ of the $10^{-1}$ to the $10^{-8}$ virus dilution series were then transferred into the 96 well plate with cells (rows A to H). Each sample was tested in quadruplicate (i.e., four columns) and one extra column contained only media (uninfected control). Cells were incubated for 6 days at $+37 \pm 1{ }^{\circ} \mathrm{C}$ with $5 \% \mathrm{CO}_{2}$ and the number of infected wells with CPE was recorded. Tissue Culture Infective Dose $\left(\mathrm{TCID}_{50}\right)$ values of $50 \%$ were calculated using the Karber formula [51]. To calculate MOIs $\left(\mathrm{MOI}=\mathrm{PFU} / \mathrm{N}^{\circ}\right.$ of cells $), \mathrm{a} \mathrm{PFU} / \mathrm{mL}$ working estimate was calculated using the formula, $1 \mathrm{TCID}_{50} / \mathrm{mL}=0.7 \mathrm{PFU} / \mathrm{mL}$.

\subsection{Virus Purification}

Purification of rBTV-1 and BTV-26 was adapted from [52]. Briefly, three T175 $\mathrm{cm}^{2}$ flasks (Greiner Bio-One, Monroe, NC, USA) of BSR cells were infected with BTV when cells were $80 \%-90 \%$ confluent and incubated at $+37{ }^{\circ} \mathrm{C}$ and $5 \% \mathrm{CO}_{2}$. When 90 to $100 \%$ of cytopathic effect (CPE) was observed (usually at around 48-72 hpi), cells were harvested and pelleted by centrifugation at $1912 \times g$ and $+4{ }^{\circ} \mathrm{C}$ for $10 \mathrm{~min}$. Supernatants were then discarded, and cell pellet re-suspended in $10 \mathrm{~mL}$ of ice-cold $0.5 \%$ Triton-TNE buffer with $1 \times$ protease inhibitor cocktail (Sigma-Aldrich ${ }^{\circledR}$, Gillingham, UK). A cytoplasmic extract was made using a hand-held glass homogeniser, then centrifuged for $10 \mathrm{~min}$ at $1000 \times \mathrm{g}$, at $+4{ }^{\circ} \mathrm{C}$. Five $\mathrm{mL}$ of the extract supernatant was kept on ice until required. The remaining $5 \mathrm{~mL}$ of extract was mixed with another $5 \mathrm{~mL}$ of $0.5 \%$ Triton-TNE with $1 \times$ Protease 
Inhibitor Cocktail and the pellet re-suspended. Manual homogenisation and the collection steps were repeated twice more, giving a final volume of collected cytoplasmic extract of $20 \mathrm{~mL}$. The pellet was discarded after this. The cytoplasmic extract was layered on a sucrose gradient consisting of $40 \% \mathrm{w} / \mathrm{v}$ sucrose with $0.1 \% \mathrm{~N}$-Lauroyl Sarcosine (NLS) $/ 0.2 \mathrm{M}$ Tris- $\mathrm{HCl} \mathrm{pH} 8.0$ on top of a $66 \% w / w$ sucrose solution, and centrifuged for $2 \mathrm{~h}$ in SW28 open tubes (Beckman Coulter, High Wycombe, UK) at 25,000 rpm (rotor Ti32), $+4{ }^{\circ} \mathrm{C}$ and lowest brake settings. Virus particles were collected from the interface between the two gradients and re-suspended with $0.1 \%$ NLS/0.2 M Tris- $\mathrm{HCl}$ pH8.0 buffer. Virus purity and viral titres $\left(3.88 \times 10^{7} \mathrm{PFU} / \mathrm{mL}\right.$ for $\mathrm{rBTV}-1$ and $1.7 \times 10^{8} \mathrm{PFU} / \mathrm{mL}$ for BTV-26) was confirmed by $10 \%$ SDS-PAGE visualised by Pierce silver staining (Thermo Fisher Scientific, Swindon, UK) and endpoint titration, respectively. Virus preparations were stored at $+4{ }^{\circ} \mathrm{C}$ until needed.

\subsection{Protein Identification by Mass Spectrometry}

Sucrose purified BTV-26 was mixed with $3 \times$ blue loading dye containing DTT (New England BioLabs ${ }^{\circledR}$, Ipswich, MA, USA) as per manufacturer's instructions. The virus-dye mixture was then heated at $95{ }^{\circ} \mathrm{C}$ for 5 min before running it in a $4-20 \%$ Criterion $^{\mathrm{TM}} \mathrm{TGX}^{\mathrm{TM}}$ Precast Midi Protein gel (Bio-Rad, Hercules, CA, USA) for $2 \mathrm{~h}$ as per manufacturer's instructions. Viral protein bands were visualised by Coomassie ${ }^{\circledR}$ blue (Thermo Fisher Scientific, Swindon, UK), Pierce silver staining or SYPRO ${ }^{\circledR}$ Ruby Protein Gel Stain (Thermo Fisher Scientific, Swindon, UK). The two bands closest to the expected molecular size of VP2 $2_{\text {BTV26 }}$ were then excised and kept in ultrapure water at $+4{ }^{\circ} \mathrm{C}$ until sequenced by mass spectrometry. Briefly, bands were destained and in-gel tryptic digestion performed essentially as described by [53]. Extracted peptides were reduced to dryness using a centrifugal vacuum concentrator (Eppendorf, Hamburg, Germany) and re-suspended in $3 \%(v / v)$ methanol, $0.1 \%(v / v)$ TFA for analysis by MS. LC-MS/MS analysis was similar to that described by [54]. Peptides were analysed by on-line nanoflow LC using the Ultimate 3000 nano system (Dionex/Thermo Fisher Scientific, Swindon, UK) coupled to a Q-Exactive mass spectrometer (Thermo Fisher Scientific, Swindon, UK). Spectral data were analysed using the PEAKS studio X+ software (Bioinformatics Solutions Inc., Waterloo, ON, Canada, [55]). Tandem MS data were searched against BTV protein database in NCBI and a contaminant database (cRAP, GPMDB, 2012). Search parameters were as follows; precursor mass tolerance set to $15 \mathrm{ppm}$ and fragment mass tolerance set to $0.02 \mathrm{Da}$. Two missed cleavage events were permitted. Carbamido-methylation (C) was set as a fixed modification and oxidation (M) and acetylation (N-term) were set as variable modifications. The search was semi-specific. The false discovery rate was set at $1 \%$.

\subsection{Fluorescent Microscopy}

Intracellular immune labelling of the viral non-structural protein 2 (NS2) was used to detect and assess the progress of virus replication over time. Fixed cells on coverslips were washed three times with calcium and magnesium free Dulbecco's phosphate buffered saline (DPBS) and permeabilised for 15 min with $0.1 \%$ Triton (Sigma-Aldrich ${ }^{\circledR}$, Gillingham, UK) in DPBS. Cells were subsequently incubated with $0.5 \%$ bovine serum albumin (BSA)/DPBS for $30 \mathrm{~min}$ at room temperature, followed up by one hour incubation with Orbivirus reference antibody 1 (Orab1), in-house, rabbit polyclonal antibodies (raised against bacterial expressed, purified NS2 of BTV-1) diluted 1:2500 in 0.5\% BSA/DPBS. Cells were washed three times with DPBS, before incubating them for one hour with goat anti-rabbit IgG Alexa Fluor $^{\circledR} 488$ secondary antibody (Life Technologies Limited, Paisley, UK), diluted 1:250 in $0.5 \%$ BSA/DPBS. After another three washes with DPBS, cellular nuclei were stained with 4', 6-Diamidino-2-phenylindole (DAPI) (Life Technologies Limited, Paisley, UK) for ten minutes. Finally, coverslips were washed in distilled water, mounted on glass slides on a drop of Vectashield ${ }^{\circledR}$ mounting medium (Vector Laboratories, Burlingame, CA, USA), sealed with nail varnish and analysed by confocal microscope (Leica SP8 CLSM, Leica Microsystems, Wetzlar, Germany). 
The percentage of infected cells was calculated by counting at least five-hundred cells (nuclei) per area and assessing for NS2 immunofluorescence. In total, three random areas per coverslip were selected, and two independent experiments were carried out.

\subsection{Binding Assay}

The ability of BTV-26 to bind KC cells was assessed by immuno-labelling of cell surface-bound virus. BTV-1 and BSR cells were used as positive controls. Briefly, BSR $\left(1 \times 10^{5}\right.$ cells $)$ or KC cells $\left(1 \times 10^{6}\right.$ cells $)$ were seeded on $13 \mathrm{~mm}$ glass coverslips in 24 well tissue culture plates (Corning ${ }^{\circledR}$ Costar ${ }^{\circledR}$, Corning Inc., Corning, NY, USA) and incubated overnight at +37 or $+28{ }^{\circ} \mathrm{C}$, respectively. Cells were then placed on ice and washed once with ice-cold calcium and magnesium free DPBS. Three hundred $\mu \mathrm{L}$ of purified virus (BTV-26 or BTV-1) was added at a MOI of 50, and cells were incubated on ice for one hour to allow virus binding to the cell, but not internalization. Inoculum was then removed and cells washed three times with ice-cold DPBS before fixing them with $4 \%$ PFA for one hour. Fixed cells were then immuno-labelled as described for intracellular immunolabelling, but without membrane permeabilization, using primary antibodies targeting virus particles (structural proteins). In-house guinea-pig Orab279 polyclonal antibody (anti-BTV-1) or goat GT01 polyclonal antibody (anti-BTV-26) were used, diluted 1:2000 or 1:1000 in 0.5\% BSA/DPBS, respectively. Cells were washed three times with DPBS, before incubating them for one hour with goat anti-guinea pig IgG Alexa Fluor ${ }^{\circledR} 488$ or donkey anti-goat IgG Alexa Fluor ${ }^{\circledR} 488$ secondary antibodies (Life Technologies Limited, Paisley, UK), diluted 1:250 in 0.5\% BSA/DPBS. After another three washes with DPBS, cellular nuclei were stained with DAPI for ten minutes. Phalloidin conjugated to Alexa Fluor ${ }^{\circledR}$ 633 dye (Life Technologies Limited, Paisley, UK) was used to stain actin filaments, as per manufacturer's instructions. Finally, coverslips were washed, mounted and analyzed by confocal microscopy as described above.

\subsection{Transmission Electron Microscopy (TEM)}

$\mathrm{KC}$ cells at a density of $7 \times 10^{5}$ cells were seeded on $13 \mathrm{~mm}$ Thermanox plastic coverslips (Thermo Fisher Scientific, Swindon, UK) and incubated overnight at $+28{ }^{\circ} \mathrm{C}$. Cells were then infected at a MOI of 5 with BTV-1, BTV-26 or rBTV- $1_{26}$ S2,S6,S7 then incubated at $+28{ }^{\circ} \mathrm{C}$. At two days pi cells were fixed in phosphate buffered $2 \%$ glutaraldehyde (Agar Scientific Ltd., Stansted, UK) for $1 \mathrm{~h}$ followed by $1 \mathrm{~h}$ in aqueous 1\% osmium tetroxide (Agar Scientific Ltd., Stansted, UK). The samples were dehydrated in an ethanol series; $70 \%$ for $30 \mathrm{~min}, 90 \%$ for $15 \mathrm{~min}$ and $100 \%$ three times for $10 \mathrm{~min}$ each. A transitional step of $10 \mathrm{~min}$ in propylene oxide (Agar Scientific Ltd., Stansted, UK) was undertaken before the samples were infiltrated with a 50:50 mix of propylene oxide and epoxy resin (Agar Scientific Ltd., Stansted, UK) for $1 \mathrm{~h}$. After a final infiltration of 100\% epoxy resin for $1 \mathrm{~h}$, the samples were embedded and polymerised overnight at $60{ }^{\circ} \mathrm{C}$. Eighty $\mu \mathrm{m}$ thin sections were cut, collected onto copper grids (Agar Scientific Ltd., Stansted, UK) and grid stained using Leica EM AC20 (Leica Microsystems, Wetzlar, Germany) before being imaged at $100 \mathrm{kV}$ in a FEI Tecnai 12 TEM with a TVIPS F214 digital camera (FEI Company, Hillsboro, OR, USA).

\subsection{Oral Infection of Adult Culicoides sonorensis Midges}

In-house laboratory-reared adult Culicoides sonorensis midges [56] were fed on BTVinfected blood meals, as previously described [18,25]. Briefly, approximately 200 two to three day old adult female $C$. sonorensis biting midges were deprived of sugar for $24 \mathrm{~h}$, before being allowed to feed on defibrinated horse blood (TCS Biosciences, Botolph Claydon, UK) containing $10^{6}$ or $10^{7} \mathrm{TCID}_{50} / \mathrm{mL}$ of BTV, using the Hemotek system (Hemotek Ltd., Blackburn, UK) with a Parafilm membrane (Cole-Parmer, Vernon Hills, IL, USA). Immediately after infection/feeding (0 days post infection (dpi)), 10 membrane-fed C. sonorensis from each group were individually homogenised in $1 \mathrm{~mL}$ of serum-free Schneider's insect medium (Sigma-Aldrich ${ }^{\circledR}$, Gillingham, UK) using $3 \mathrm{~mm}$ round metal beads and a Qiagen Tissue Lyser (Qiagen, Hilden, Germany). The remaining blood-fed insects were incubated 
for 8 days at $+25 \pm 1{ }^{\circ} \mathrm{C}$ with access to $10 \%$ sucrose diluted in water (on cotton wool pads). At the end of the incubation period, individual Culicoides midges were homogenized and RNA was extracted from $100 \mu \mathrm{L}$ of midge homogenate using a Kingfisher ${ }^{\mathrm{TM}}$ Flex robot and the LSI MagVet ${ }^{\mathrm{TM}}$ Universal Isolation Kit (Thermo Fisher Scientific, Swindon, UK) as per manufacturer's instructions. Virus levels were measured using a BTV qRT-PCR assay targeting Seg-9 [50]. Vector competence rates (proportion of midges with transmissible levels of viral RNA) were calculated as the proportion of midges with significantly higher amounts of viral RNA at $8 \mathrm{dpi}$, compared to 0 dpi $[25,29,57]$.

\subsection{Statistical Analysis}

For all experiments, results were plotted using the GraphPad Prism software version 7.00 (GraphPad Software, San Diego, CA, USA). The specific statistical test carried out is described in each figure legend. For oral infection of adult $C$. sonorensis midges, sample size was calculated prior to the experiments, using a test for two proportions using Minitab, version 18 (Minitab LLC, State College, PA, USA). Size sample calculated was 95 individuals for each group, with the following assumptions: power value $=0.8$; baseline $p=0.18$; comparison $p=0.05$ and significance level $=0.05$. Since data from vector competence studies was not normally distributed, non-parametric tests were chosen to analyse the data. Comparison of two populations was carried out with Mann Whitney test, while for comparison of multiple groups, Krustal-Wallis test was used. Vector competence rates were estimated with $95 \%$ confidence intervals using a one-sample proportion test.

\section{Results}

\subsection{BTV-26 KUW2010/02 Is Unable to Replicate in Arthropod-Derived Cells In Vitro}

The inability of BTV-26 to infect and replicate in adult Culicoides sonorensis, or the C. sonorensis-derived KC cell line, which are both susceptible to infection by classical BTV strains $[18,19,58]$, led us to ask whether BTV-26 could be vectored by other arthropod species. Our previous study showed low levels of replication of BTV-26 in immunedeficient C6/36 mosquito cells [19]. Therefore, we also assessed the ability of BTV-26 to replicate in several other arthropod-derived cell lines, including U4.4 cells (derived from Aedes albopictus mosquitoes), RAE25 cells (from Rhipicephalus appendiculatus ticks) and HAE/CTVM9 cells (from Hyalomma anatolicum ticks). Host-relevant Bovine Foetal Aorta endothelium cells (BFA) were included for comparison, as a positive control for effective viral replication.

Both rBTV-1 and BTV-26 replicated effectively in bovine BFA cells (Figure 1A) plateauing at approximately $10^{9}$ genome copies $/ \mathrm{mL}$ between 72 and $96 \mathrm{hpi}$. Infection of the mosquito cell line U4.4 with rBTV-1 (Figure 1B) resulted in exponential virus replication from 2 to $7 \mathrm{dpi}$, which peaked at approximately $10^{9}$ genome copies $/ \mathrm{mL}$. In contrast, there was an overall decrease in BTV-26 genome copy numbers in these mosquito cells (Figure 1B) by the end of the experiment at $10 \mathrm{dpi}$, compared to the viral inoculum at 0 hpi. Infection of the tick cell lines RAE25 and HAE/CTVM9 with rBTV-1, or BTV-26 (Figure 1C) showed no increase in either infectivity or genome copy numbers during the first 10 days pi. Media changes at 10 and 20 dpi led to some fluctuations of BTV RNA detection in the collected supernatants (Figure 1C), although overall amounts of viral genome copies still decreased between 0 and $30 \mathrm{dpi}$ for both BTV-1 and BTV-26 in the tick cell lines RAE25 and HAE/CTVM9. Overall, these results show that BTV-26 is not able to successfully propagate in these arthropod-derived cell lines. 
A

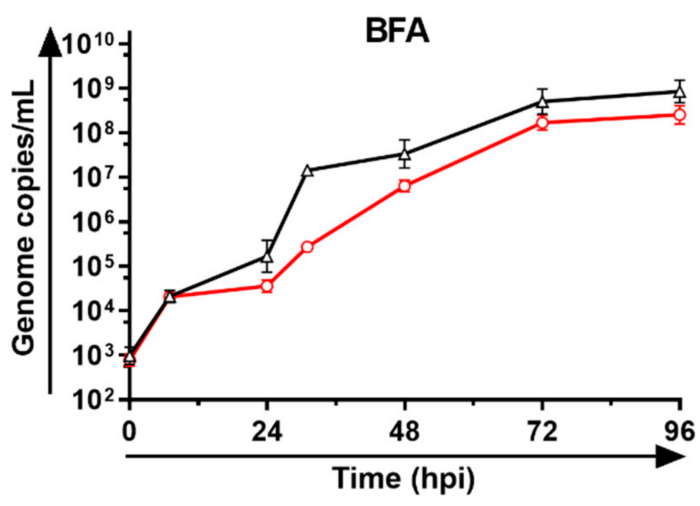

C
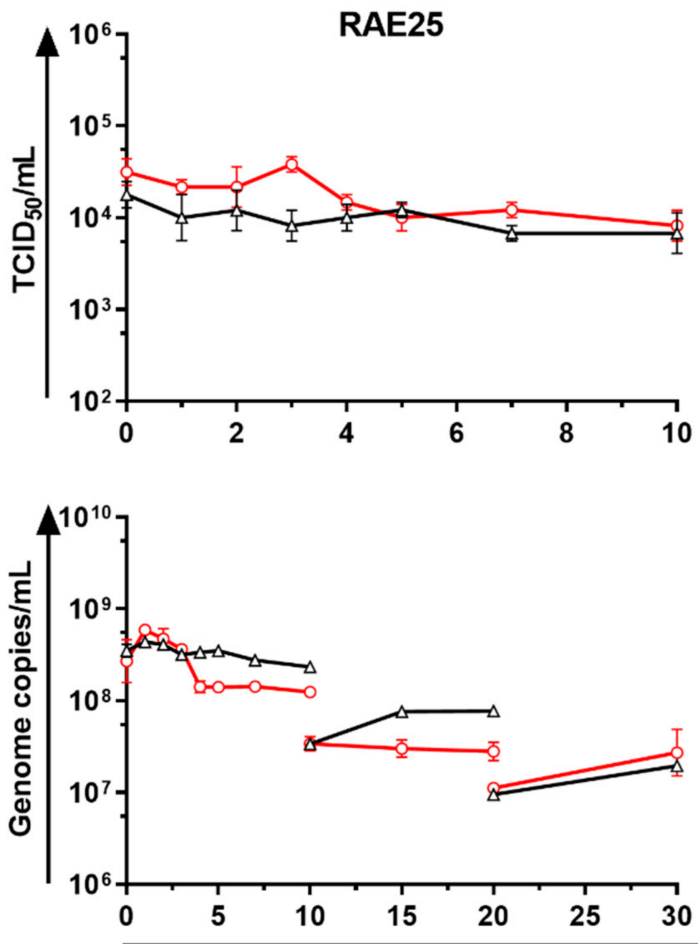

B

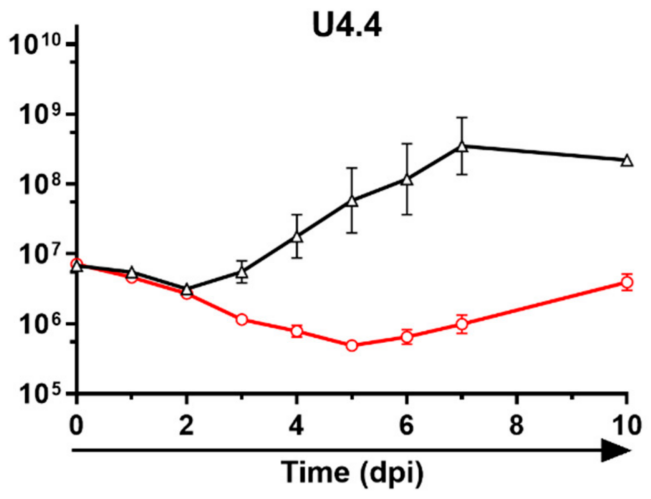

HAE/CTVM9
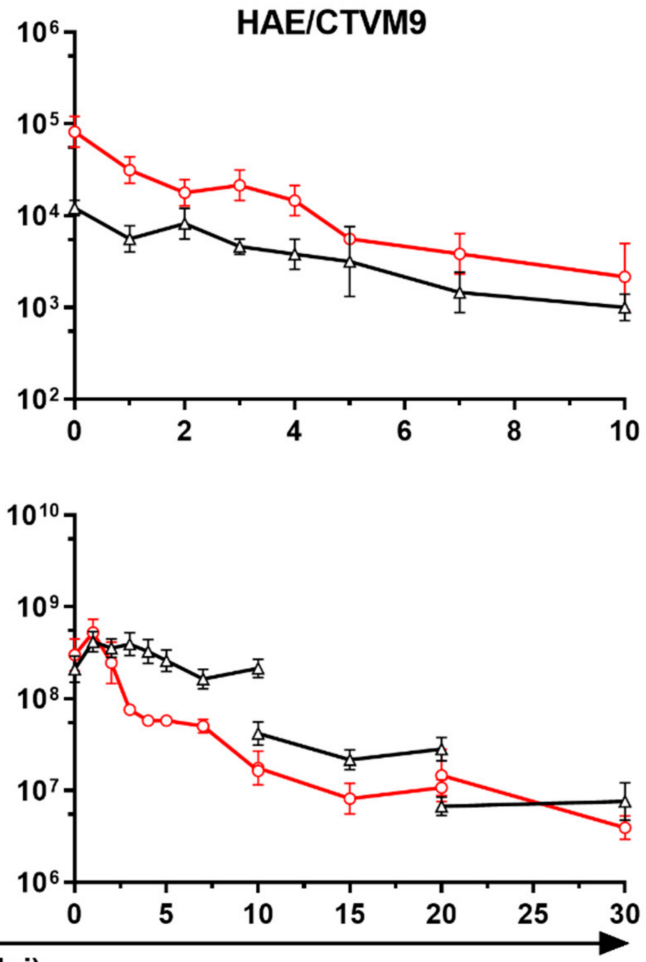

Time (dpi)

$\triangle-$ rBTV-1 $-\circ$ BTV-26

Figure 1. Replication kinetics of BTV-1 and BTV-26 in mammalian and arthropod cell lines. Bovine-BFA cells (A) were seeded at a density of $1.00 \times 10^{5}$ cells/well. Aedes-U4.4 cells (B) were seeded at a density of $2.50 \times 10^{7}$ cells/flask. In (C), tick-derived Rhipicephalus appendiculatus-RAE25 cells or Hyalomma anatolicum-HAE/CTVM9 cells were seeded at a density of $2.40 \times 10^{6}$ cells/tube or $2.00 \times 10^{6}$ cells/tube, respectively. Cells were infected at a MOI of $0.01(\mathbf{A}, \mathbf{B})$ or $1(\mathbf{C})$ with rBTV-1 (black triangles) or BTV-26 (red circles). Infected BFA cells were incubated at $+37^{\circ} \mathrm{C}$ with $\mathrm{CO}_{2}$, while U4.4 were incubated at $+28{ }^{\circ} \mathrm{C}$ without $\mathrm{CO}_{2}$ and tick cells at $+32{ }^{\circ} \mathrm{C}$ without $\mathrm{CO}_{2}$. In all panels, $250 \mu \mathrm{L}$ of supernatant were collected at each indicated time point. BTV genome copy numbers were determined using the qRT-PCR BTV Seg-9 assay [50] on extracted RNA and the results are expressed as the mean of genome copies $/ \mathrm{mL}$ of two independent experiments $(\mathbf{A}, \mathbf{B})$ or one experiment in triplicate $(\mathbf{C}) \pm$ standard error of the mean. In (C), $50 \mu \mathrm{L}$ of supernatant were used to calculate $50 \%$ tissue culture infective dose $\left(\mathrm{TCID}_{50} / \mathrm{mL}\right)$ in BSR cells.

\subsection{Cell Binding Studies of Purified BTV-26 in Culicoides-Derived Cells}

To elucidate the mechanism/s that restrict BTV-26 infection and propagation in arthropod cells, we next started interrogating the replication cycle of BTV-26 in cells derived from 
vector-competent midges (KC cells). The ability of purified BTV-26 virus particles to attach to Culicoides (KC) and mammalian (BSR) cell-surfaces was first investigated.

Initially, the integrity of purified BTV-1 and BTV-26 particles was tested by electrophoresis in 10\% SDS-PAGE gel. The protein migration patterns of purified virus particles (Figure 2A), showed a band at the size of the sub-core protein VP3 of BTV-26 (94 kDa), but not at the predicted size of outer-capsid and cell-attachment protein VP2 $(111 \mathrm{kDa})$ of BTV-26, suggesting that either VP2 and VP3 of BTV-26 (VP2 ${ }_{\text {BTV26 }}$ and VP3 ${ }_{\text {BTV26) co-migrate }}$ under these conditions or that $\mathrm{VP} 2_{\mathrm{BTV} 26}$ might have detached from the particle during the purification process. However, analysis in a $4 \%-20 \%$ gradient gel (Figure $2 \mathrm{~B}$ ) did show two bands at $\sim 94 \mathrm{kDa}$. Subsequent mass spectrophotometry on the two bands confirmed that VP2 ${ }_{\text {BTV26 }}$ was present in our purified BTV-26 preparations (Figure 2C), but most likely migrated faster than VP2 ${ }_{\mathrm{BTV}}$ and below VP3, even though the predicted molecular weight for both VP2 proteins should be very similar at around $111 \mathrm{kDa}$, and bigger than their respective VP3 proteins. This also suggests that VP2 and VP3 of BTV-26 co-migrate in $10 \%$ gels.

A

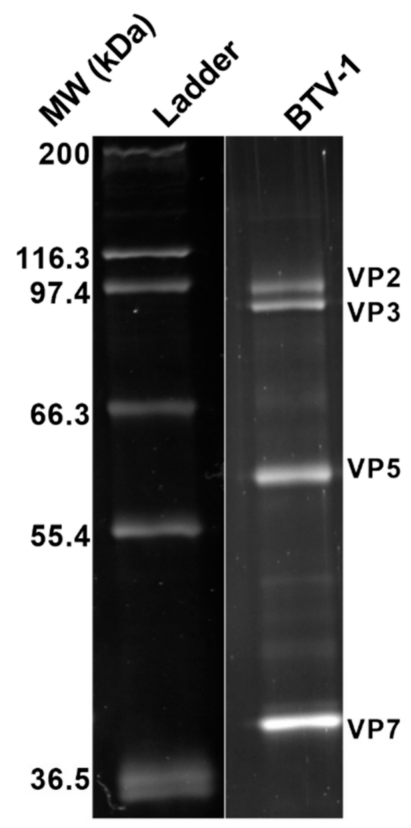

B

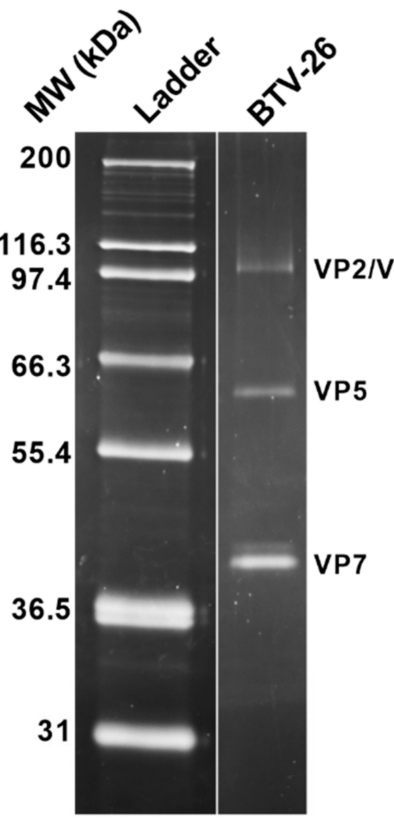

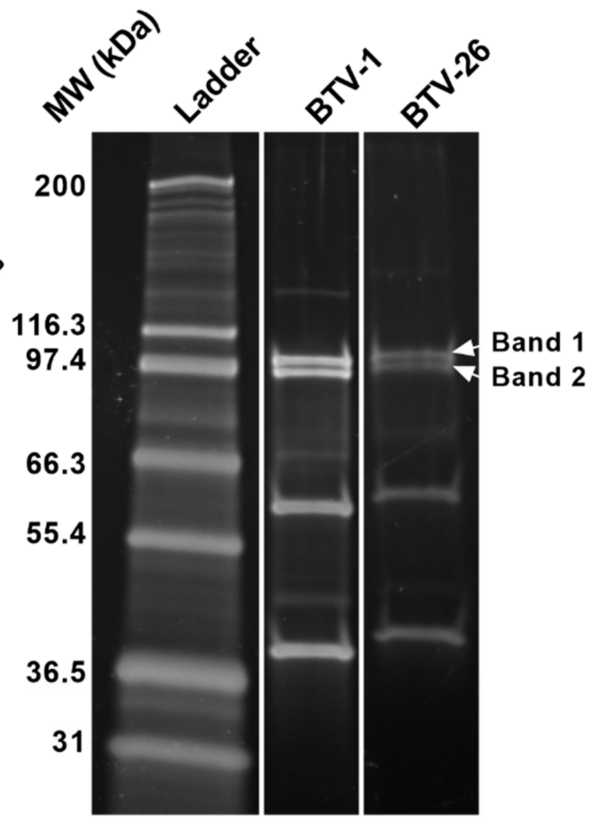

\section{C}

\begin{tabular}{llllll}
\hline $\begin{array}{l}\text { Protein } \\
\text { band (in B) }\end{array}$ & $\begin{array}{l}\text { BTV protein } \\
\text { detected }\end{array}$ & $\begin{array}{l}\text { Coverage } \\
(\%)\end{array}$ & $\begin{array}{l}\text { Unique } \\
\text { peptides }\end{array}$ & $\begin{array}{l}\text { Spectral } \\
\text { counts }\end{array}$ & $\begin{array}{l}\text { Proposed } \\
\text { ID }\end{array}$ \\
\hline \multirow{3}{*}{1} & VP3 & 57 & 52 & 124 \\
\cline { 2 - 5 } & VP2 & 56 & 58 & 93 \\
\cline { 2 - 5 } 2 & Others & 4 & 2 & 2 & 124 \\
& VP2 & 66 & 78 & 89 \\
\cline { 2 - 5 } & VP3 & 50 & 40 & 4 & VP2 \\
\cline { 2 - 5 } & Others & 6 & 4 & & \\
\hline
\end{tabular}

Figure 2. Protein profile of BTV-26 particles and VP2 identification. Purified particles of rBTV-1 and BTV-26 were run in a 10\% SDS-PAGE gel (A) or a 4\%-20\% Gradient SDS-PAGE gel (B) and stained with SYPRO ${ }^{\circledR}$ Ruby protein gel stain. BTV particles consists of 3 protein layers: the capsid (VP2 and VP5), the outer core (VP7) and the inner core (VP3). In (A,B), ladder is Mark12 ${ }^{\mathrm{TM}}$ Unstained Standard. Sequencing of Bands 1 and 2 (in B) by mass-spectrophotometry identified them as BTV-26 VP3 and VP2, respectively (C). 
Having confirmed that our BTV-26 had not lost cell attachment protein VP2 during purification, cell-binding experiments were carried out. Detection of virus bound to the cell surface confirmed the ability of BTV-26 capsid proteins to mediate attachment to mammalian BSR cells (Figure 3A). However, BTV-26 particles were not detected on the surface of KC cells in comparable binding experiments (Figure 3B), indicating that they do not bind efficiently to these insect cells. As KC cells are smaller in size than mammalian BSR cells, we demonstrated that visualization of virus particle binding was not affected by the cell size and that binding of rBTV-1 particles to KC cell membranes was readily detectable (Figure 3B).
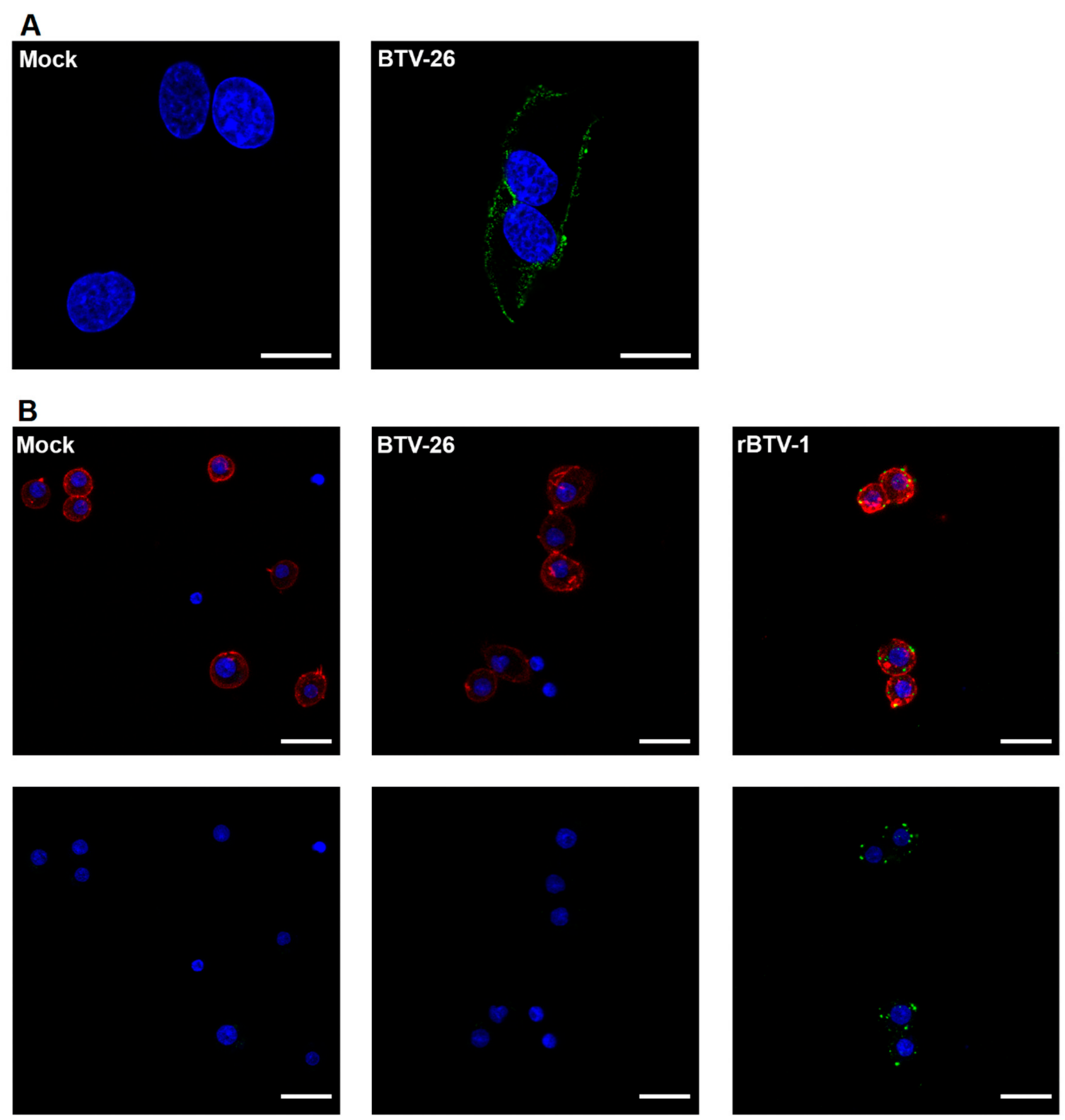

Figure 3. Binding ability of BTV-26 in mammalian and Culicoides midge cells. BSR (A) or KC (B) cells were either mock infected or infected with purified rBTV-1 (B only) or BTV-26 (A,B) at a MOI of 100 (A) or 50 (B) in ice-cold conditions to prevent virus internalization. After $60 \mathrm{~min}$, cells were washed three times with ice-cold serum-free medium, fixed with 4\% PFA and labelled for DNA (DAPI-blue), Actin (Phalloidin-633, red) and BTV-1 (Orab279-Alexa Fluor 488, green) or BTV-26 (GT0128-Alexa Fluor 488, green). Cells were visualized by confocal laser scanning microscopy. In (A), the scale bar represents $20 \mu \mathrm{m}$ for all panels, while in (B), the scale bar represents $5 \mu \mathrm{m}$, and it is a representative image of 3 experiments. 


\subsection{The Ability of the BTV-26 Capsid to Block Virus Replication in KC Cells}

Having found that BTV-26 is deficient in its ability to bind to the surface of KC cells, we next investigated if this was mediated solely by its capsid proteins or if conditions such as temperature and MOI might mitigate the low binding and facilitate viral replication. The outer-capsid (VP2 and VP5) and outer-core (VP7) proteins of BTV play multiple roles at different stages of the BTV replication cycle. These include cell attachment, internalization of virus particles, and release of transcriptionally active core-particles into the cell cytoplasm, as well as later stages such as assembly and release of progeny virus particles [59].

$\mathrm{KC}$ cells were infected at a low MOI $\left(0.01 \mathrm{TCID}_{50} /\right.$ cell $)$ at $27^{\circ} \mathrm{C}$ with parental strains BTV-26 or rBTV-1, and virus release into the supernatant was measured up to 10 days pi. A reverse engineered virus $\left(\mathrm{rBTV}-1_{26} \mathrm{S2}, \mathrm{S} 6, \mathrm{~S} 7\right)$ containing three major capsid and core proteins, VP2, VP5 and VP7 derived from BTV-26, in a BTV-1 genetic backbone (Table 1, [19]), was also included in these experiments. Although, as previously shown [19], rBTV-1 replicated and was amplified in KC cells, BTV-26 and rBTV- $1_{26}$ S2,S6,S7 failed to propagate effectively, with viral-genome copy numbers increasing only slightly in the supernatant between days 0 and 2 pi, then remaining unchanged for the rest of the experiment (Figure 4). Next, we investigated whether increasing the MOI 100-fold (MOI of 1) would overcome any obstacle to replication and propagation caused by for example, an inefficient cell-entry process. However, at this MOI, BTV-26 and rBTV-1 $1_{26} \mathrm{S2,S6,S7}$ still failed to replicate efficiently or spread in $\mathrm{KC}$ cell cultures at $27^{\circ} \mathrm{C}$, with only a minor increase in supernatant genome copy numbers between 0 and $2 \mathrm{dpi}$ (from $\sim 10^{6}$ to $\sim 10^{7}$ copies $/ \mathrm{mL}$ ), which then remained "flat" until 10 dpi (Figure 4).
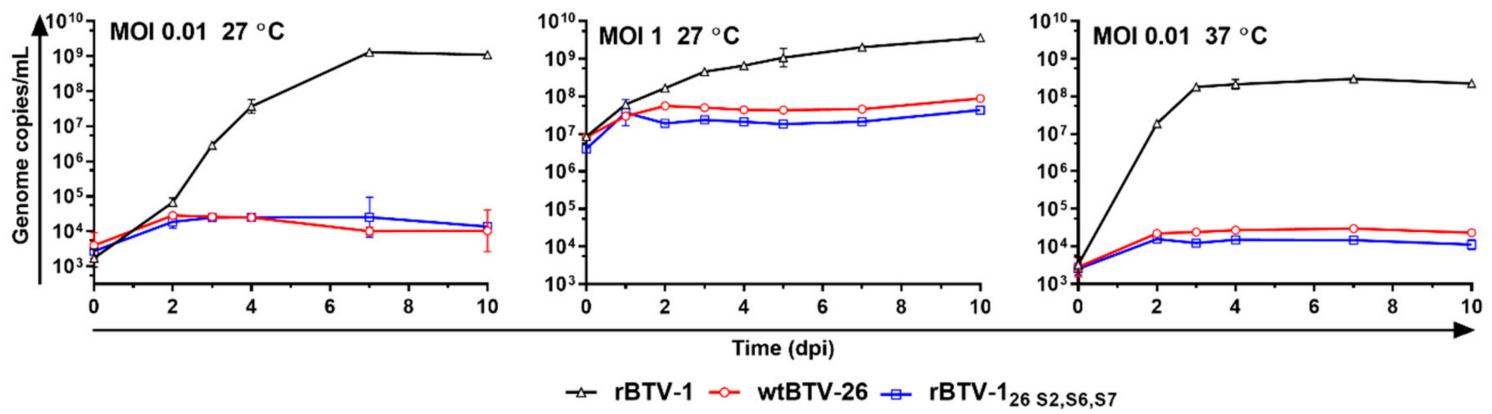

Figure 4. Replication kinetics of rBTV-1, BTV-26 and rBTV-1 26 S2,S6,S7 in Culicoides cells under several conditions. KC cells were seeded at a density of $7.00 \times 10^{5}$ cells/well on coverslips, and infected at a MOI of 0.01 or 1 , with rBTV-1 (black triangles), BTV-26 (red circles) or $\mathrm{rBTV}-1_{26} \mathrm{~S} 2, \mathrm{~S} 6, \mathrm{~S} 7$ (blue squares). Infected cells were incubated at $+27^{\circ} \mathrm{C}$ or $37^{\circ} \mathrm{C}$ without $\mathrm{CO}_{2}$. Two hundred and fifty $\mu \mathrm{L}$ of supernatant were collected at each indicated time point, and total RNA extracted from $100 \mu \mathrm{L}$ of supernatant. BTV genome copy numbers were determined using the qRT-PCR BTV Seg-9 assay [50]. Results are expressed as the mean of genome copies $/ \mathrm{mL}$ of two independent experiments \pm standard error of the mean.

BSR and $\mathrm{KC}$ cell cultures are usually grown at $37^{\circ} \mathrm{C}$ and $27^{\circ} \mathrm{C}$, respectively. Infection of KC cells with rBTV- 1 at $37^{\circ} \mathrm{C}$ resulted in faster replication than at $27^{\circ} \mathrm{C}$, plateauing after $3 \mathrm{dpi}$ instead of at $7 \mathrm{dpi}$ (Figure 4). However, when $\mathrm{KC}$ cells were infected at $37^{\circ} \mathrm{C}$ with BTV-26, or rBTV- $1_{26} \mathrm{S2,S6,57}$, there was no significant increase in virus copy numbers up to $10 \mathrm{dpi}$, with kinetics very similar to infections at $27^{\circ} \mathrm{C}$, indicating that both viruses again failed to replicate and amplify successfully.

\subsection{The Capsid of BTV-26 Blocks the Early Stages of Virus Replication Cycle in KC Cells}

BTV non-structural protein 2 (NS2) is synthesized soon after the virus core enters the cell cytoplasm and initiates viral mRNA synthesis [60]. NS2 can therefore be used as a marker for the early stages of replication, indicating that cell-entry, mRNA synthesis and translation have occurred. NS2 was detected at 2 dpi in $4.6 \%$ of KC cells infected with rBTV- 1 at a low MOI of 0.01 , increasing to $67 \%$ of cells at 4 dpi (Figure $5 \mathrm{~A}, \mathrm{~B}$ ), showing that the virus had successfully entered the cells, initiated mRNA and protein synthesis, and 
was spreading effectively to other cells. In contrast, NS2 was detected in $<0.05 \%$ of KC cells infected with BTV-26 at either 2 or 4 dpi, confirming that infection and virus replication are severely restricted (Figure 5A,B).

A
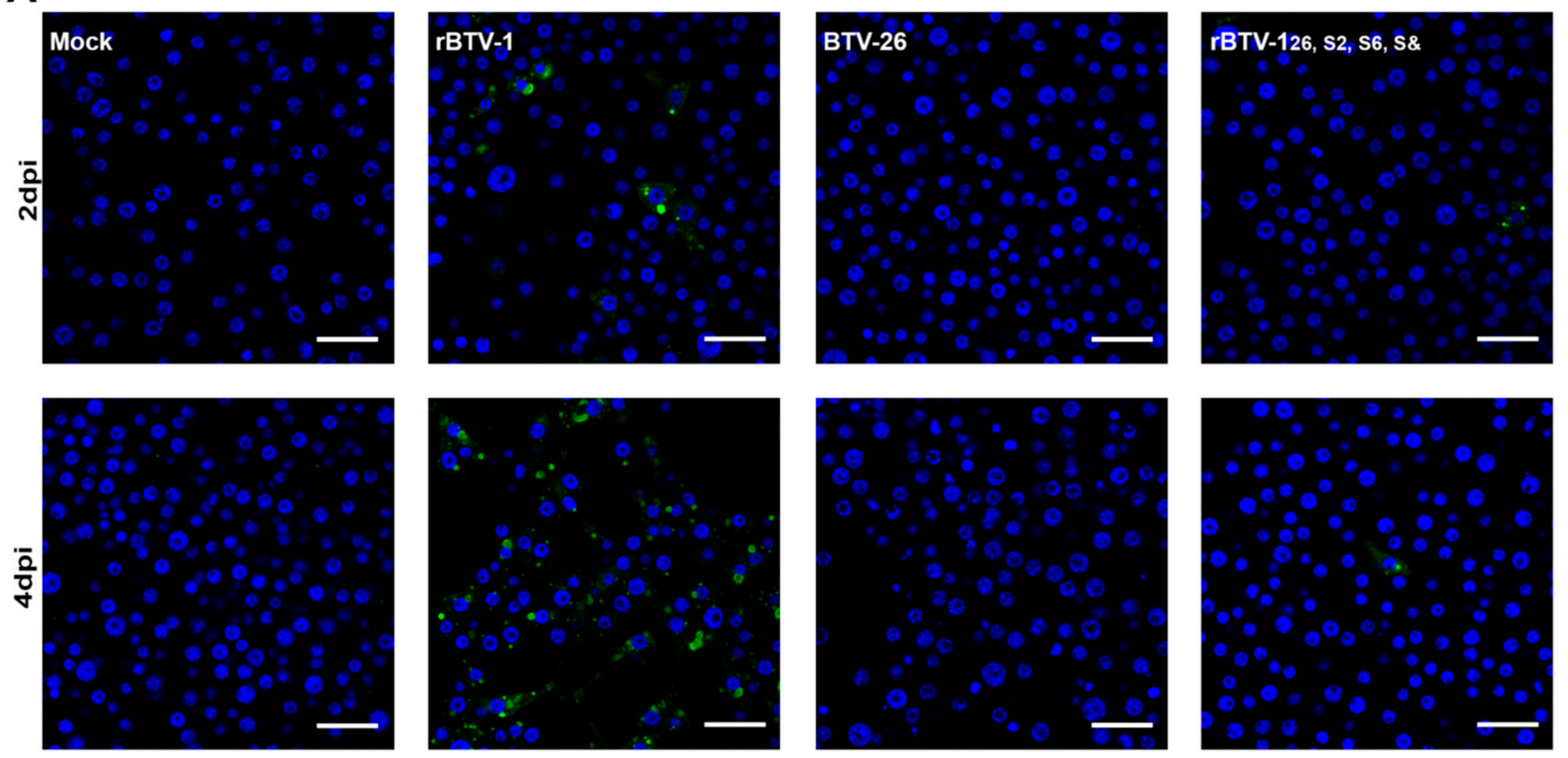

B
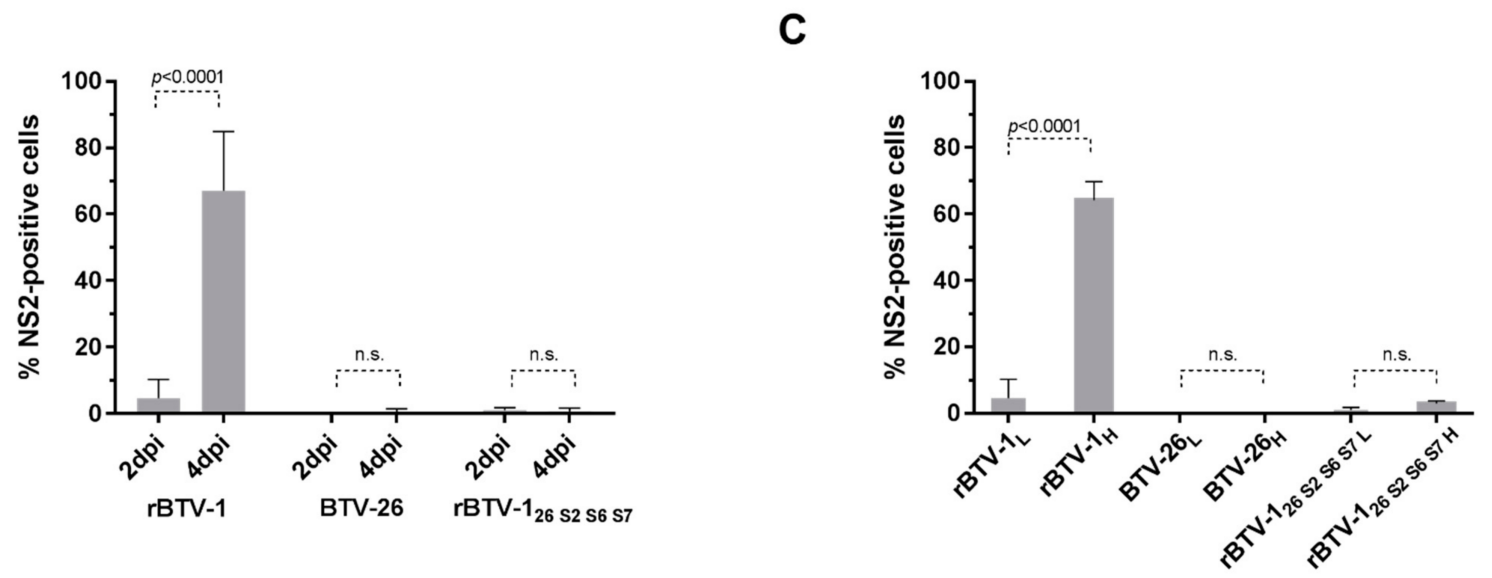

Figure 5. Intracellular replication of rBTV-1, BTV-26 and rBTV-1 $26 \mathrm{S2,S6,S7}$ in Culicoides cells. KC cells were seeded at a density of 7.00E+05 cells/well on coverslips in a 24-well plate at a low MOI of $0.01(\mathbf{A}, \mathbf{B})$. At 2 or 4 days pi cells were fixed with $4 \%$ PFA and labelled for DNA (DAPI, in blue) and viral NS2 (Orab1-Alexa Fluor 488, in green). Cells were visualized by confocal laser scanning microscopy (A) and the percentage of NS2 positive cells from two independent experiments calculated (over 3000 cells counted) (B). In (A), the scale bar represents $10 \mu \mathrm{m}$ for all panels. In (C), a comparison of the percentage of NS2 positive cells at 2 dpi between KC cells infected at low (L) MOI (0.01) or high (H) MOIs (1-5) is shown. Means were compared by carrying out ANOVA tests: a Sidak's multiple comparison test (B) or a Tukey's multiple comparison test $(\mathbf{C})$.

However, low numbers of KC cells did become infected with rBTV-1 26 S2,S6,57 at an MOI of 0.01 , with NS2 detected at both 2 and 4 dpi (in $1 \%$ and $0.75 \%$ of the cells, respectively) (Figure 5A,B), suggesting that a low level of cell entry and initiation of viral RNA transcription and protein translation had been achieved, but infection did not progress or spread to additional cells over this time period. With a 100 -fold increase of the MOI (MOI of 1 or 5) (Figure 5C), NS2 was still undetected in KC cells infected with BTV-26. However, a slight increase in the number of cells expressing NS2 (2.92 \%) was observed at 2 dpi with rBTV-1 26 S2,S6,S7. Together with the results already described (Figures 3 and 4), this indicates that early stages of the viral replication cycle are strongly restricted by the capsid proteins of BTV-26, although if this block is overcome, at least some of the later 
stages of virus replication can proceed, albeit seemingly not resulting in significant spread of infection to other cells.

Transmission Electron Microscopy (TEM) of pelleted KC cells infected at an MOI of 5 with rBTV-1, BTV-26 or rBTV-1 $26 \mathrm{S2,S6,S7}$ (Figure 6), confirmed that a few cells were actively infected with rBTV-1 $1_{26} \mathrm{~S} 2, \mathrm{~S} 6, \mathrm{~S} 7$ at $2 \mathrm{dpi}$. These cells contained viral inclusion bodies (VIBs), (composed of NS2), viral 'tubules' (composed of NS1) and newly assembled core particles in the cell cytoplasm, demonstrating that viral mRNA/protein synthesis and core particle assembly had occurred. However, whole virus particles were not seen in these infected cells, suggesting that there might be other blocks late in the replication and assembly pathway of rBTV-1 $1_{26}$ S2,S6,S7 in KC cells, again possibly mediated by VP2 of BTV-26.
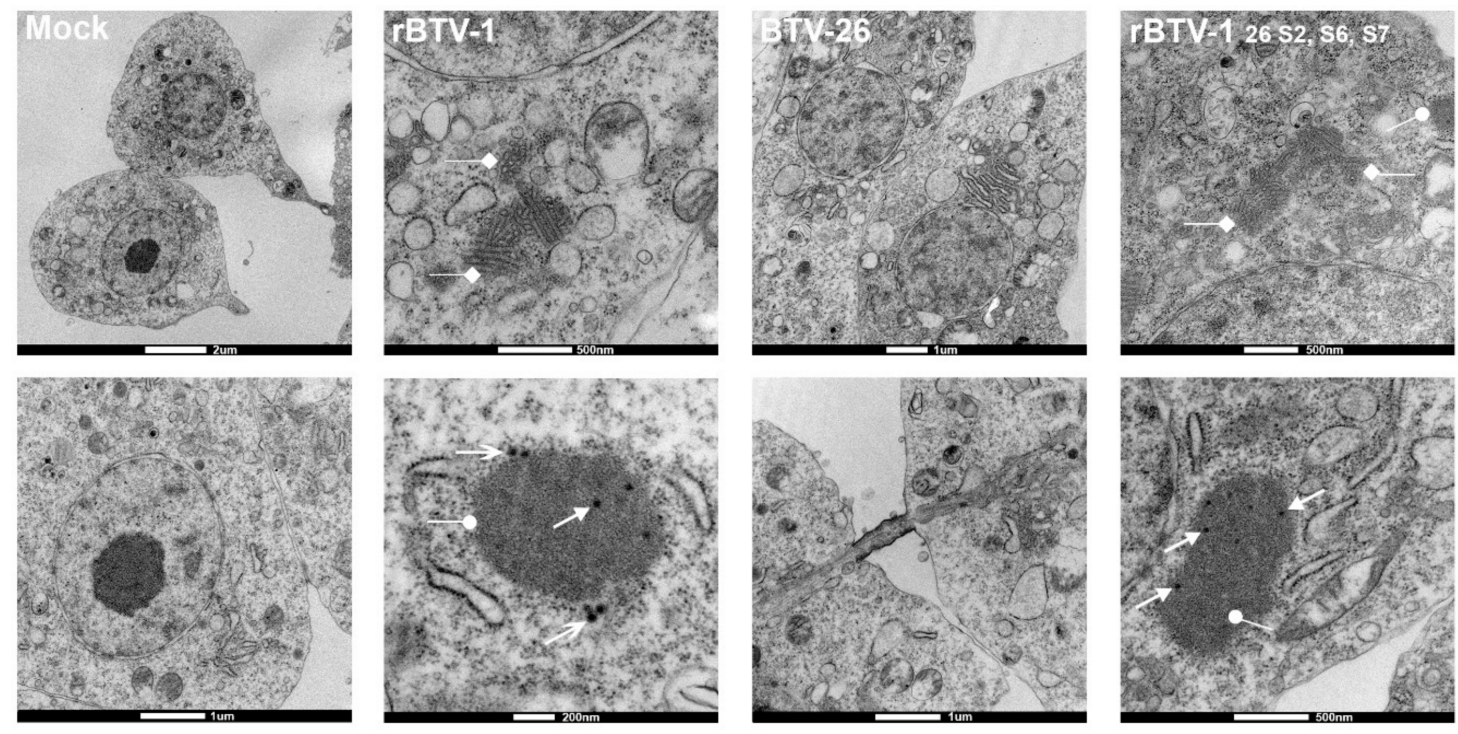

Figure 6. Transmission electron microscopy (TEM) of Culicoides cells infected with rBTV-1, BTV-26 or rBTV-1 26 S2,S6,S7. KC cells on coverslips were either mock infected or infected at a MOI of 5 and incubated at $+27^{\circ} \mathrm{C}$ with rBTV-1, BTV-26, or rBTV-1 26 S2,S6,S7. At 2 dpi, cells were fixed with phosphate buffered $2 \%$ glutaraldehyde. Cells were visualised by TEM (FEI Tecnai 12 TEM with a TVIPS F214 digital camera). Open arrows show whole virus particles (only in rBTV-1), arrows show viral core particles, ovals show viral inclusion bodies (VIBs) made of NS2, and diamonds show viral microtubules made of NS1.

VIBs, NS1 tubules, or core particles were not observed in KC cells infected at a high MOI with BTV-26. When internalization of a few BTV-26 particles could occur (as suggested by the data with $\mathrm{rBTV}-1_{26 \mathrm{~S} 2, \mathrm{S6}, \mathrm{S7}}$ ), both immunofluorescence staining and TEM failed to detect replication of BTV-26. This suggests additional blocks to virus replication mediated by other proteins of BTV-26 such as VP1, or VP3 of BTV-26 [19].

\subsection{Capsid Proteins of BTV-26 Restrict BTV Replication in Adult C. sonorensis}

The biological importance of the in vitro results presented was assessed by orally infecting adult female Culicoides sonorensis midges, with blood meals containing rBTV-1, BTV-26 or rBTV- $1_{26} \mathrm{S2}, 56,57$. Virus replication was measured at 8 days post feeding (dpf), and vector competence ratios were determined as previously described [25].

Initial infections of $C$. sonorensis adults with $10^{6} \mathrm{TCID}_{50}$ of virus $/ \mathrm{mL}$ of blood (a viral load similar to the average peak viraemia in an infected ruminant) revealed a low competence rate for rBTV-1 (1.39\%) (Figure S1a), suggesting that the reverse engineered rBTV-1 was a poor positive control for infection. Direct comparison with other BTV-1 strains and conditions of infection (Figure S1) showed that the vector competence of $C$. sonorensis for $\mathrm{rBTV}-1$ was significantly lower than for the reference strain (RSArrrr/01) (identified here as wild type (wt) BTV-1). Interestingly, passage of rBTV-1 in KC cells (rBTV-1 KC) prior to infecting $C$. sonorensis increased viral replication efficiency of this "synthetic" virus within the vector insects. Although beyond the scope of this study, this suggests a role for viral variants and strain-diversity in infection and replication efficiency. 
As rBTV-1 (BSR cell passaged) was, however, needed as matched positive control for BTV 26 and rBTV-1 $1_{26} \mathrm{S2,S6,S7}$, we investigated whether the vector competence rate of $C$. sonorensis for rBTV-1 could be increased by raising the viral dose in the blood meal [39]. Orally infecting $C$. sonorensis midges with a 10-fold increase in the amount of rBTV-1 showed a significant increase in vector competence rate (Figure S1d,e). Therefore, subsequent infections of adult midges with BTV-26 and $\mathrm{rBTV}-1_{26}$ S2,S6,S7 were carried out using blood meals containing $10^{7} \mathrm{TCID}_{50} / \mathrm{mL}$ of virus.

Analysis of midges orally infected with blood containing $10^{7} \mathrm{TCID}_{50} / \mathrm{mL}$ of $\mathrm{rBTV}-1$ (Figure 7A) showed that 139 out of 140 individuals (99.29\%) contained detectable levels of viral RNA (vRNA) on day 8 pf. Midges that were positive for vRNA, could be divided into two significantly different subpopulations, which we identified as "competent" and "non-competent" based on significantly higher or lower amounts of vRNA compared to levels in midges at $0 \mathrm{dpf}$ (Median $\mathrm{Ct}_{\text {competent }}=19.02$ vs: $\mathrm{Ct}_{\text {day } 0}=24.30, p \leq 0.001$ : Median $\mathrm{Ct}_{\text {non-competent }}=33.55$ vs: $\left.\mathrm{Ct}_{\text {day } 0}=24.30, p \leq 0.001\right)$. Twenty-six midges had higher vRNA levels than midges on day $0 \mathrm{pf}$, indicating that $18.56 \%$ (95\% CI: $12.50-26.01 \%$ ) of the midges were vector-competent for rBTV-1.

A

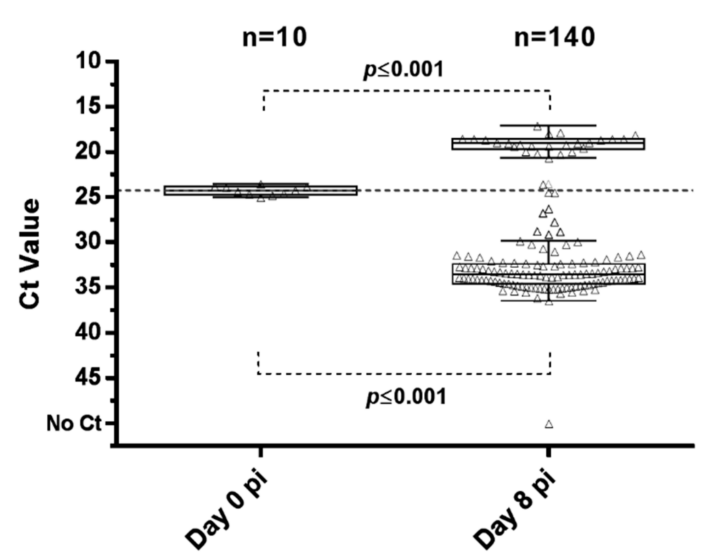

C

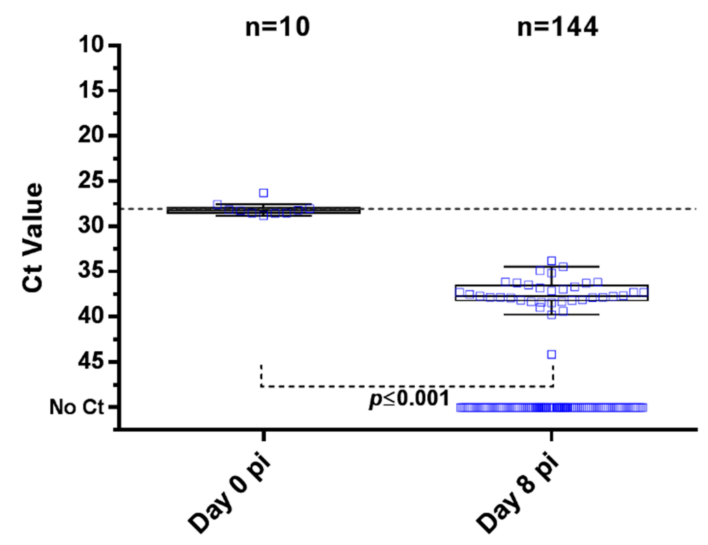

B

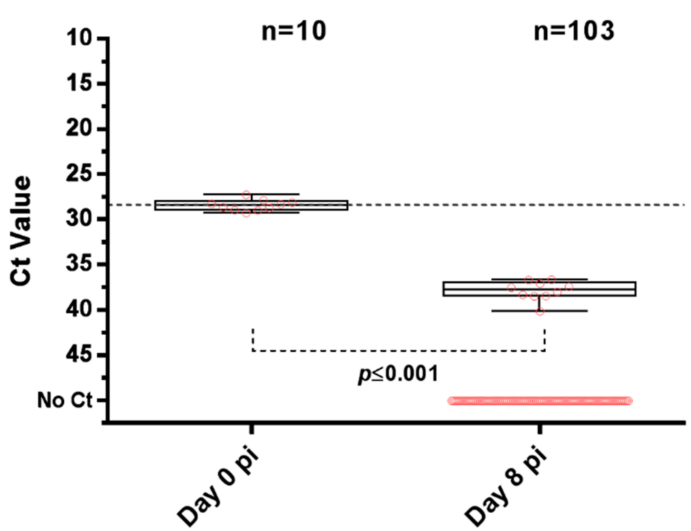

D

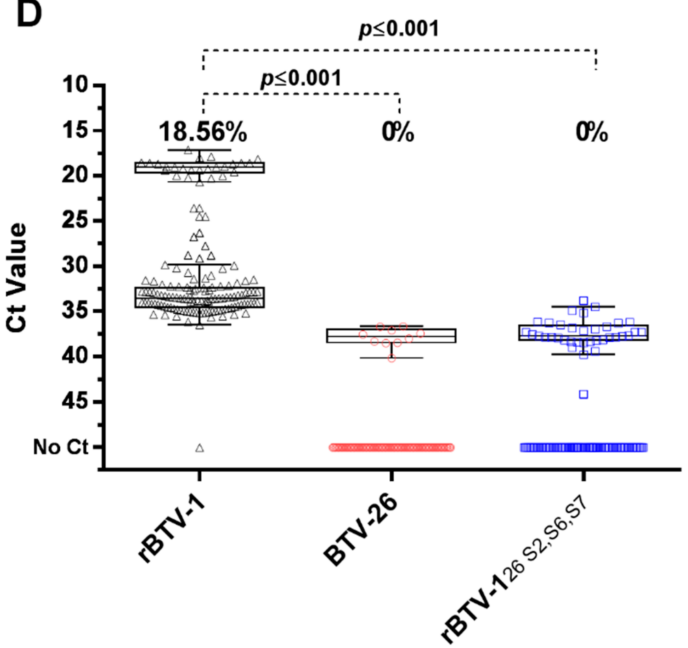

Figure 7. Oral infection of adult Culicoides sonorensis midges with rBTV-1, BTV-26 and rBTV-1 $26 \mathrm{S2,S6,S7}$. Plotted results for 0 and $8 \mathrm{dpi}$ of adult female $C$. sonorensis orally infected with $10^{7} \mathrm{TCID}_{50} / \mathrm{mL}$ of $(\mathbf{A}) \mathrm{rBTV}-1 ;(\mathbf{B}) \mathrm{BTV}-26$; and $(\mathbf{C}) \mathrm{rBTV}-1_{26} \mathrm{S2,S6,S7}$. In (A-C) dotted lines show the threshold that indicates viral levels of transmissibility/vector competence. Box-and-whiskers show median (line), 1st and 3rd quartiles (25th and 75th percentiles) of the different determined populations (Whiskers were defined by the Tukey method, and comparison of medians by Mann-Whitney test). Comparison of all groups at $8 \mathrm{dpi}$ is shown in (D), where calculated competence rates are shown as percentages (2 proportions comparison-Minitab). In all panels each symbol represents one individual midge. 
None of the surviving 103 midges fed with BTV-26 at $10^{7} \mathrm{TCID}_{50} / \mathrm{mL}$ (Figure 7B) had viral RNA levels at $8 \mathrm{dpf}$ above those at $0 \mathrm{dpf}$, indicating a competence rate of $0 \%$ (95\% CI: 0-2.87\%). The median Ct for the 10 RNA positive but non-competent midges (Median $\left.\mathrm{Ct}_{\text {non-competent }}=37.74\right)$ was significantly higher $(p \leq 0.001)$ than that on $0 \mathrm{dpf}$ $\left(\mathrm{Ct}_{\text {day } 0}=29.26\right)$.

None of the 144 midges that were orally infected with $\mathrm{rBTV}^{-1}{ }_{26} \mathrm{~S} 2, \mathrm{~S} 6, \mathrm{~S} 7$ had levels of vRNA on $8 \mathrm{dpf}$ that indicated virus replication to transmissible levels (Figure 7C). Thirty-six midges had low vRNA levels at $8 \mathrm{dpf}$, significantly below values on $0 \mathrm{dpf}\left(\mathrm{Ct}_{\mathrm{day} 0}=28.23\right.$, $p \leq 0.001$ ), identifying them as non-competent (Median $\left.\mathrm{Ct}_{\text {day } 8}=37.67\right)$. This confirms that the capsid proteins of BTV-26 not only restrict viral infection and replication in Culicoides cells in vitro, but also restrict BTV replication in adult BTV-competent $C$. sonorensis midges.

\section{Discussion}

The work presented shows that replication of the 'atypical' BTV-26 (strain KUW2010/02) is severely restricted in numerous arthropod cells (results summarized in Table 3), including cells derived from the BTV-vector spp. Culicoides sonorensis (KC cells), as well as in adult C. sonorensis midges. We show for the first time that the inability of BTV-26 to complete its replication cycle in $\mathrm{KC}$ cells starts with a block in the early stages of its replication, including a greatly reduced ability of the virus to bind to the surface of $\mathrm{KC}$ cells. This block is mediated by capsid proteins of BTV-26, preventing amplification and propagation of the virus in vivo within the insect-vector.

Table 3. Summary of the ability of rBTV-1 and BTV-26 to replicate in several mammalian and arthropod-derived cell lines.

\begin{tabular}{lccc}
\hline Cell Line/Organism & rBTV-1 & BTV-26 & rBTV-1 $_{26 S 2, \text { S6, S7 }}$ \\
\hline BSR (Hamster-fibroblasts) & + & + & +1 \\
\hline BFA (Bovine-aorta endothelium) & + & + & NA \\
\hline KC (C. sonorensis midge-larvae) & + & - & - \\
\hline U4.4 (A. albopictus mosquito-) & + & - & NA \\
\hline RAE25 (R. appendiculatus tick-) & - & - & NA \\
\hline HAE/CTVM9 (H. anatolicum tick-) & - & NA \\
\hline Adult C. sonorensis midges & + & - \\
\hline${ }^{\prime \prime}$ indicates efficient replication, whereas "- indicates severely deficient or no replication at all; ${ }^{1}$ in [19].
\end{tabular}

The BTV outer-capsid is composed of the two most variable virus proteins (VP2 and VP5), which are involved in cell attachment (via VP2) and penetration of the cell membrane (via VP5), during the early stages of infection by intact virus particles in both mammalian and insect cells [37]. BTV core particles that have lost their outer coat proteins VP2 and VP5 can also initiate cell entry in KC cells, and less efficiently in some mammalian cells (e.g., BHK but not $\mathrm{CHO}$ (Chinese Hamster Ovary cells)), mediated by the core-surface protein VP7 [39,52]. Our previous research showed that mono-reassortant BTV-1 viruses containing either VP5 or VP7 derived from BTV-26 can replicate in both KC and BSR cells, while BTV-26 and rBTV-1 26 S2,S6,S7 can replicate in mammalian BSR cells but not in KC cells (this study and [19]). We therefore conclude that the failure of rBTV- $1_{26} \mathrm{S2,S6,S7}$ to infect and replicate in Culicoides cells is most likely due to VP2 of BTV-26.

Although not strictly quantitative and potentially missing low frequency events, confocal microscopy suggests that BTV-26 is largely unable to attach to the $C$. sonorensis

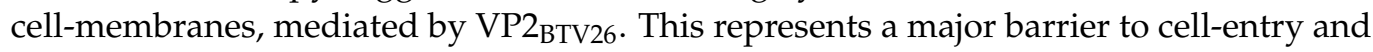
infection, preventing productive replication, demonstrated by a failure to detect NS2 synthesis by BTV-26 in KC cell. The cell-receptors for BTV binding have not yet been identified in either mammalian or insect cells, although there is evidence to suggest that BTV uses different entry pathways and therefore possibly different receptors, depending on serotype, target cell and viral particle type [35,36,38,40,52]. 
However, BTV-26 does bind to permissive mammalian BSR, or bovine BFA cells, in both cases leading to infection and amplification of the virus genome. This confirms that VP2 of BTV-26 is a fully functional mammalian-cell-attachment protein. Protein sequencing by mass spectrometry confirmed the presence of VP2 in purified BTV-26 particles, as well as suggesting that it migrates faster on SDS-PAGE gels than VP2 ${ }_{\text {BTV-1 }}$, even though both proteins have a similar predicted size, and no obvious differences in hydrophobicity and charge (using https:/ / www.expasy.org/resources/protparam, accessed on 25 February 2021). Whether there are still differences in their folding and/or post-translation modifications, which could potentially also explain differences in their cell attachment properties, needs to be further investigated.

A small number of $\mathrm{KC}$ cells did become infected with $\mathrm{rBTV}-1_{26} \mathrm{S2}, \mathrm{S6}, \mathrm{S} 7$, resulting in viral protein synthesis and at least the early stages of replication and particle assembly, generating VIBs, tubules and core particles, as detected by TEM. In contrast to rBTV-1, fully intact virus particles were not identified in the cytoplasm of rBTV- $1_{26} \mathrm{S2,S6,S7}$ infected KC cells, although the very small percentage of cells infected by this reassortant virus limits the conclusions that can be drawn by TEM. This low level of infection might reflect binding and entry of alternative particle types (e.g., core particles or membrane enveloped virus particles (MEVP) [61]) that are likely to be present in tissue culture-derived virus stocks). In addition to a block in the initial stages of cell binding and entry, the failure of rBTV$1_{26}$ S2,S6,S7 to spread to other cells in KC cultures might reflect additional blocks to either the final assembly of the outer-capsid of progeny virus particles, or a failure of any intact virus particles generated to be released from infected cells, processes that would both involve VP2 of BTV-26, as well as its effective interactions with internal components/proteins of the insect cells [62-65].

In summary, our results support the hypothesis that $C$. sonorensis is not able to act as a vector for BTV-26 KUW2010/02, and that BTV-26 might not be a vector-borne virus. Together with previous evidence of direct-contact transmission [18,21], our results provide further critical evidence that direct-contact rather than insect vectors constitute its main route of transmission Further research is required to determine if this applies to other strains of atypical BTV serotypes $[20,66]$ or if they could be vectored by other arthropods, including other Culicoides species. VP2 is the most variable BTV protein and the respective VP2s of the BTV-1 and BTV-26 strain utilized in this study only share $38.5 \%$ similarity in their aa sequence (GenBank accession numbers BTV-1 VP2: FJ969720.1/BTV-26 VP2: HM590642.1). Furthermore, only recently have some parts of the overall VP2 structure of BTV-1 been modelled and proposed $[37,67]$. Nonetheless, further work on VP2 2 BTV26 could focus on identifying domains, motifs, residues, and cell surface proteins involved in binding of VP2 ${ }_{\text {BTV26 }}$ to mammalian cells and its inability to bind to KC cells $[37,67,68]$. This could potentially also shed light on viral genetic determinants required for directcontact transmission.

Results presented here highlight the importance of studying the atypical BTV strains, despite their low pathogenicity, as they can exchange genome-segments (reassort) with conventional BTV strains, generating novel progeny viruses with unpredictable phenotypes. This could potentially result in the emergence of economically significant BTV strains that do not require vectors for transmission, potentially extending their seasonal and geographic range. The atypical BTV strains, "engineered" reassortant viruses and KC cells provide useful tools to address questions relating to BTV/vector interactions, cell tropism, transmission mechanisms and determinants of virulence. With the recent detection of additional atypical serotypes $[16,43]$, their epidemiological importance and occurrence appears to be greater than initially anticipated.

Supplementary Materials: The following are available online at https:/ / www.mdpi.com/article/10 .3390/v13050919/s1, Figure S1: Oral infection of adult Culicoides sonorensis midges with different variants of BTV-1. 
Author Contributions: Conceptualization, M.G.B., G.D.P., K.E.D., M.P., R.F. and P.P.C.M.; Formal analysis, M.G.B., S.A. and J.S.; Funding acquisition, K.E.D. and P.P.C.M.; Investigation, M.G.B., L.C., S.A. and J.S.; Supervision, G.D.P., M.P., R.F. and P.P.C.M.; Writing-original draft, M.G.B., K.E.D., R.F. and P.P.C.M.; Writing-review \& editing, M.G.B., G.D.P., K.E.D., L.C., S.A., J.S., M.P., R.F. and P.P.C.M. All authors have read and agreed to the published version of the manuscript.

Funding: This research was partially funded by a Pirbright studentship (BBS/E/I/00001876-supporting M.G.B.) and by the United Kingdom Biotechnology and Biological Sciences Research Council (BBSRC) funding through BB/E/I/00007033 and BB/E/I/00007034 (supporting M.G.B.). The study was additionally supported by Defra R\&D project SE2621 and the European Commission Horizon 2020 PALE-Blu project (727393). The work at the Pirbright Institute is further enabled by BBSRC funding $\mathrm{BB} / \mathrm{E} / \mathrm{I} / 00007037$ and the Bioimaging and Insectary facilities support through BB/E/I/00007039.

Institutional Review Board Statement: Not applicable.

Informed Consent Statement: Not applicable.

Data Availability Statement: All data are contained within the article.

Acknowledgments: The authors would like to thank Lesley Bell-Sakyi for kindly providing the tick cell lines used in this study, Mark Boyce and Houssam Attoui for useful and interesting discussions, and Eric Denison for the supply of Culicoides sonorensis midges.

Conflicts of Interest: The authors declare no conflict of interest. The funders had no role in the design of the study; in the collection, analyses, or interpretation of data; in the writing of the manuscript, or in the decision to publish the results.

\section{References}

1. Alexander, K.A.; MacLachlan, N.J.; Kat, P.W.; House, C.; O’Brien, S.J.; Lerche, N.W.; Sawyer, M.; Frank, L.G.; Holekamp, K.; Smale, L.; et al. Evidence of natural bluetongue virus infection among African carnivores. Am. J. Trop. Med. Hyg. 1994, 51, 568-576. [CrossRef] [PubMed]

2. Jauniaux, T.P.; De Clercq, K.E.; Cassart, D.E.; Kennedy, S.; Vandenbussche, F.E.; Vandemeulebroucke, E.L.; Vanbinst, T.M.; Verheyden, B.I.; Goris, N.E.; Coignoul, F.L. Bluetongue in Eurasian lynx. Emerg. Infect. Dis. 2008, 14, 1496-1498. [CrossRef] [PubMed]

3. Meyer, G.; Lacroux, C.; Leger, S.; Top, S.; Goyeau, K.; Deplanche, M.; Lemaire, M. Lethal bluetongue virus serotype 1 infection in llamas. Emerg. Infect. Dis. 2009, 15, 608-610. [CrossRef] [PubMed]

4. World Organisation for Animal Health (OIE): Paris, France. Available online: https://www.oie.int/en/what-we-do/animalhealth-and-welfare/animal-diseases/? / (accessed on 14 May 2021).

5. Hewat, E.H.; Booth, T.F.; Roy, P. Structure of bluetongue virus particles by cryoelectron microscopy. J. Struct. Biol. 1992, 109, 61-69. [CrossRef]

6. Mertens, P.P.C.; Maan, S.; Samuel, A.; Attoui, H. Orbivirus, Reoviridae; Virus Taxonomy VIIIth Report of the ICTVC; Fauquet, M., Mayo, M.A., Maniloff, J., Desselberger, U., Ball, L.A., Eds.; Elsevier/Academic Press: London, UK, 2004.

7. Maan, S.; Maan, N.S.; Samuel, A.R.; Rao, S.; Attoui, H.; Mertens, P.P.C. Analysis and phylogenetic comparisons of full-length VP2 genes of the 24 bluetongue virus serotypes. J. Gen. Virol. 2007, 88, 621-630. [CrossRef]

8. Gibbs, E.P.J.; Lawman, M.J.P.; Herniman, K.A.J. Preliminary observations on transplacental infection of bluetongue virus in sheep-Possible overwintering mechanism. Res. Vet. Sci. 1979, 27, 118-120. [CrossRef]

9. Menzies, F.D.; McCullough, S.J.; McKeown, I.M.; Forster, J.L.; Jess, S.; Batten, C.; Murchie, A.K.; Gloster, J.; Fallows, J.G.; Pelgrim, W.; et al. Evidence for transplacental and contact transmission of bluetongue virus in cattle. Vet. Rec. 2008, 163, 203-209. [CrossRef]

10. Darpel, K.E.; Batten, C.A.; Veronesi, E.; Williamson, S.; Anderson, P.; Dennison, M.; Clifford, S.; Smith, C.; Philips, L.; Bidewell, C.; et al. Transplacental transmission of bluetongue virus 8 in cattle, UK. Emerg. Infect. Dis. 2009, 15, 2025-2028. [CrossRef]

11. Borkent, A. The pupae of the biting midges of the world (Diptera: Ceratopogonidae), with a generic key and analysis of the phylogenetic relationships between genera. Zootaxa 2014, 3879, 1-327. [CrossRef]

12. Purse, B.V.; Carpenter, S.; Venter, G.J.; Bellis, G.; Mullens, B.A. Bionomics of temperate and tropical Culicoides midges: Knowledge gaps and consequences for transmission of Culicoides-borne viruses. Annu. Rev. Entomol. 2015, 60, 373-392. [CrossRef]

13. Purse, B.V.; Mellor, P.S.; Rogers, D.J.; Samuel, A.R.; Mertens, P.P.C.; Baylis, M. Climate change and the recent emergence of bluetongue in Europe. Nat. Rev. Microbiol. 2005, 3, 171-181. [CrossRef]

14. Mellor, P.S.; Carpenter, S.; Harrup, L.; Baylis, M.; Mertens, P.P.C. Bluetongue in Europe and the Mediterranean Basin: History of occurrence prior to 2006. Prev. Vet. Med. 2008, 87, 4-20. [CrossRef]

15. Curini, V.; Marcacci, M.; Tonelli, A.; Di Teodoro, G.; Di Domenico, M.; D’Alterio, N.; Portanti, O.; Ancora, M.; Savini, G.; Panfili, M.; et al. Molecular typing of Bluetongue virus using the nCounter ${ }^{\circledR}$ analysis system platform. J. Virol. Methods 2019, 269, 64-69. [CrossRef] 
16. Ries, C.; Sharav, T.; Tseren-Ochir, E.O.; Beer, M.; Hoffmann, B. Putative novel serotypes ‘33' and '35' in clinically healthy small ruminants in Mongolia expand the group of atypical BTV. Viruses 2020, 13, 42. [CrossRef]

17. Hofmann, M.A.; Renzullo, S.; Mader, M.; Chaignat, V.; Worwa, G.; Thuer, B. Genetic characterization of toggenburg orbivirus, a new bluetongue virus, from goats, Switzerland. Emerg. Infect. Dis. 2008, 14, 1855-1861. [CrossRef]

18. Batten, C.; Darpel, K.; Henstock, M.; Fay, P.; Veronesi, E.; Gubbins, S.; Graves, S.; Frost, L.; Oura, C. Evidence for Transmission of Bluetongue virus serotype 26 through direct contact. PLoS ONE 2014, 9, e96049. [CrossRef]

19. Pullinger, G.D.; Guimera Busquets, M.; Nomikou, K.; Boyce, M.; Attoui, H.; Mertens, P.P. Identification of the genome segments of Bluetongue virus serotype 26 (Isolate KUW2010/02) that restrict replication in a Culicoides sonorensis cell line (KC cells). PLoS ONE 2016, 11, e0149709. [CrossRef]

20. Breard, E.; Schulz, C.; Sailleau, C.; Bernelin-Cottet, C.; Viarouge, C.; Vitour, D.; Guillaume, B.; Caignard, G.; Gorlier, A.; Attoui, $\mathrm{H}$; et al. Bluetongue virus serotype 27: Experimental infection of goats, sheep and cattle with three BTV-27 variants reveal atypical characteristics and likely direct contact transmission BTV-27 between goats. Transbound. Emerg. Dis. 2018, 65, e251-e263. [CrossRef]

21. Lorusso, A.; Baba, D.; Spedicato, M.; Teodori, L.; Bonfini, B.; Marcacci, M.; Di Provvido, A.; Isselmou, K.; Marini, V.; Carmine, I.; et al. Bluetongue virus surveillance in the Islamic Republic of Mauritania: Is serotype 26 circulating among cattle and dromedaries? Infect. Genet. Evol. 2016, 40, 109-112. [CrossRef]

22. Jennings, D.M.; Mellor, P.S. Variation in the responses of Culicoides variipennis (Diptera, Ceratopogonidae) to oral infection with Bluetongue virus. Arch. Virol. 1987, 95, 177-182. [CrossRef]

23. Tabachnick, W.J. Genetic control of oral susceptibility to infection of Culicoides variipennis with Bluetongue virus. Am. J. Trop. Med. Hyg. 1991, 45, 666-671. [CrossRef] [PubMed]

24. Fu, H.; Leake, C.J.; Mertens, P.P.C.; Mellor, P.S. The barriers to bluetongue virus infection, dissemination and transmission in the vector, Culicoides variipennis (Diptera: Ceratopogonidae). Arch. Virol. 1999, 144, 747-761. [CrossRef] [PubMed]

25. Veronesi, E.; Antony, F.; Gubbins, S.; Golding, N.; Blackwell, A.; Mertens, P.P.C.; Brownlie, J.; Darpel, K.E.; Mellor, P.S.; Carpenter, $\mathrm{S}$. Measurement of the infection and dissemination of Bluetongue virus in Culicoides biting midges using a semi-quantitative RT-PCR assay and isolation of infectious virus. PLoS ONE 2013, 8, e70800. [CrossRef] [PubMed]

26. Tabachnick, W.J. Nature, nurture and evolution of intra-species variation in mosquito arbovirus transmission competence. Int. J. Environ. Res. Public Health 2013, 10, 249-277. [CrossRef]

27. Severson, D.W.; Behura, S.K. Genome investigations of vector competence in aedes aegypti to inform novel arbovirus disease control approaches. Insects 2016, 7, 58. [CrossRef]

28. Mills, M.K.; Michel, K.; Pfannenstiel, R.S.; Ruder, M.G.; Veronesi, E.; Nayduch, D. Culicoides-Virus interactions: Infection barriers and possible factors underlying vector competence. Curr. Opin. Insect. Sci. 2017, 22, 7-15. [CrossRef]

29. Feenstra, F.; Drolet, B.S.; Boonstra, J.; van Rijn, P.A. Non-Structural protein NS3/NS3a is required for propagation of bluetongue virus in Culicoides sonorensis. Parasites Vectors 2015, 8, 476. [CrossRef]

30. Belhouchet, M.; Mohd Jaafar, F.; Firth, A.E.; Grimes, J.M.; Mertens, P.P.; Attoui, H. Detection of a fourth orbivirus non-structural protein. PLoS ONE 2011, 6, e25697. [CrossRef]

31. Ratinier, M.; Caporale, M.; Golder, M.; Franzoni, G.; Allan, K.; Nunes, S.F.; Armezzani, A.; Bayoumy, A.; Rixon, F.; Shaw, A.; et al. Identification and characterization of a novel non-structural protein of bluetongue virus. PLoS Pathog. 2011 , 7, e1002477. [CrossRef]

32. Stewart, M.; Hardy, A.; Barry, G.; Pinto, R.M.; Caporale, M.; Melzi, E.; Hughes, J.; Taggart, A.; Janowicz, A.; Varela, M.; et al. Characterization of a second open reading frame in genome segment 10 of bluetongue virus. J. Gen. Virol. 2015, 96, $3280-3293$. [CrossRef]

33. Stuart, D.I.; Gouet, P.; Grimes, J.M.; Malby, R.; Diprose, J.M.; Zientara, S.; Burroughs, J.N.; Mertens, P.P.C. Structual studies of orbivirus particles. Arch. Virol. 1998, 14, 235-250.

34. Grimes, J.M.; Burroughs, J.N.; Gouet, P.; Diprose, J.M.; Malby, R.; Ziéntara, S.; Mertens, P.P.C.; Stuart, D.I. The atomic structure of the bluetongue virus core. Nature 1998, 395, 470-478. [CrossRef]

35. Forzan, M.; Marsh, M.; Roy, P. Bluetongue virus entry into cells. J. Virol. 2007, 81, 4819-4827. [CrossRef]

36. Gold, S.; Monaghan, P.; Mertens, P.; Jackson, T. A clathrin independent macropinocytosis-like entry mechanism used by bluetongue virus-1 during infection of BHK cells. PLoS ONE 2010, 5, e11360. [CrossRef]

37. Zhang, X.; Patel, A.; Celma, C.C.; Yu, X.; Roy, P.; Zhou, Z.H. Atomic model of a nonenveloped virus reveals pH sensors for a coordinated process of cell entry. Nat. Struct. Mol. Biol. 2016, 23, 74-80. [CrossRef]

38. Stevens, L.M.; Moffat, K.; Cooke, L.; Nomikou, K.; Mertens, P.P.C.; Jackson, T.; Darpel, K.E. A low-passage insect-cell isolate of bluetongue virus uses a macropinocytosis-like entry pathway to infect natural target cells derived from the bovine host. J. Gen. Virol. 2019, 100, 568-582. [CrossRef]

39. Mertens, P.P.C.; Burroughs, J.N.; Walton, A.; Wellby, M.P.; Fu, H.; O'Hara, R.S.; Brookes, S.M.; Mellor, P.S. Enhanced infectivity of modified Bluetongue virus particles for two insect cell lines and for two Culicoides vector species. Virology 1996, $217,582-593$. [CrossRef]

40. Darpel, K.E.; Langner, K.F.A.; Nimtz, M.; Anthony, S.J.; Brownlie, J.; Takamatsu, H.-H.; Mellor, P.S.; Mertens, P.P.C. Saliva proteins of vector Culicoides modify structure and infectivity of bluetongue virus particles. PLoS ONE 2011, 6, e17545. [CrossRef] 
41. Maan, S.; Maan, N.S.; Nomikou, K.; Veronesi, E.; Bachanek-Bankowska, K.; Belaganahalli, M.N.; Attoui, H.; Mertens, P.P. Complete genome characterisation of a novel 26th bluetongue virus serotype from Kuwait. PLoS ONE 2011, 6, e26147. [CrossRef]

42. Schulz, C.; Breard, E.; Sailleau, C.; Jenckel, M.; Viarouge, C.; Vitour, D.; Palmarini, M.; Gallois, M.; Hoper, D.; Hoffmann, B.; et al. Bluetongue virus serotype 27: Detection and characterization of two novel variants in Corsica, France. J. Gen. Virol. 2016, 97, 2073-2083. [CrossRef]

43. Bumbarov, V.; Golender, N.; Jenckel, M.; Wernike, K.; Beer, M.; Khinich, E.; Zalesky, O.; Erster, O. Characterization of bluetongue virus serotype 28. Transbound. Emerg. Dis. 2020, 67, 171-182. [CrossRef] [PubMed]

44. Yang, H.; Gu, W.; Li, Z.; Zhang, L.; Liao, D.; Song, J.; Baoxin, S.; Hasimu, J.; Li, Z.; Yang, Z.; et al. Novel putative Bluetongue virus serotype 29 isolated from inapparently infected goat in Xinjiang of China. Transbound. Emerg. Dis. 2021, 1-13. [CrossRef]

45. Sato, M.; Maeda, N.; Yoshida, H.; Urade, M.; Saito, S. Plaque formation of herpes virus hominis type 2 and rubella virus in variants isolated from the colonies of BHK21/WI-2 cells formed in soft agar. Arch. Virol. 1977, 53, 269-273. [CrossRef]

46. Wechsler, S.J.; McHolland, L.E.; Tabachnick, W.J. Cell-Lines from Culicoides variipennis (Diptera, Ceratopogonidae) support replication of Bluetongue virus. J. Invertebr. Pathol. 1989, 54, 385-393. [CrossRef]

47. Miller, M.L.; Brown, D.T. Morphogenesis of Sindbis virus in three subclones of Aedes albopictus (mosquito) cells. J. Virol. 1992, 66, 4180-4190. [CrossRef]

48. Kurtti, T.J.; Munderloh, U.G.; Samish, M. Effect of medium supplements on tick cells in culture. J. Parasitol. 1982, 68, 930-935. [CrossRef]

49. Bell-Sakyi, L. Continuous cell lines from the tick Hyalomma anatolicum anatolicum. J. Parasitol. 1991, 77, 1006-1008. [CrossRef]

50. Maan, N.S.; Maan, S.; Belaganahalli, M.; Pullinger, G.; Montes, A.J.A.; Gasparini, M.R.; Guimera, M.; Nomikou, K.; Mertens, P.P.C. A quantitative real-time reverse transcription PCR (qRT-PCR) assay to detect genome segment 9 of all 26 bluetongue virus serotypes. J. Virol. Methods 2015, 213, 118-126. [CrossRef]

51. Kärber, G. Beitrag zur kollektiven Behandlung pharmakologischer Reihenversuche [A contribution to the collective treatment of a pharmacological experimental series]. Arch. Exp. Pathol. Pharmakol. 1931, 162, 480-483. [CrossRef]

52. Mertens, P.P.C.; Burroughs, J.N.; Anderson, J. Purification and properties of virus-particles, infectious subviral particles, and cores of Bluetongue virus serotype-1 and serotype-4. Virology 1987, 157, 375-386. [CrossRef]

53. Shevchenko, A.; Tomas, H.; Havlis, J.; Olsen, J.V.; Mann, M. In-Gel digestion for mass spectrometric characterization of proteins and proteomes. Nat. Protoc. 2006, 1, 2856-2860. [CrossRef] [PubMed]

54. Aljabr, W.; Armstrong, S.; Rickett, N.Y.; Pollakis, G.; Touzelet, O.; Cloutman-Green, E.; Matthews, D.A.; Hiscox, J.A. High resolution analysis of respiratory syncytial virus infection in vivo. Viruses 2019, 11, 926. [CrossRef] [PubMed]

55. Ma, B.; Zhang, K.; Hendrie, C.; Liang, C.; Li, M.; Doherty-Kirby, A.; Lajoie, G. PEAKS: Powerful software for peptide de novo sequencing by tandem mass spectrometry. Rapid. Commun. Mass. Spectrom. 2003, 17, 2337-2342. [CrossRef] [PubMed]

56. Boorman, J. The maintenance of laboratory colonies of Culicoides variipennis (Coq), C. nubeculosus (Mg) and C.riethi Kieff. (Diptera, Ceratopogonidae). Bull. Entomol. Res. 1974, 64, 371-377. [CrossRef]

57. Veronesi, E.; Mertens, P.P.C.; Shaw, A.E.; Brownlie, J.; Mellor, P.S.; Carpenter, S.T. Quantifying bluetongue virus in adult Culicoides biting midges (Diptera: Ceratopogonidae). J. Med Entomol. 2008, 45, 129-132. [CrossRef]

58. Batten, C.A.; Henstock, M.R.; Bin-Tarif, A.; Steedman, H.M.; Waddington, S.; Edwards, L.; Oura, C.A. Bluetongue virus serotype 26: Infection kinetics and pathogenesis in Dorset Poll sheep. Vet. Microbiol. 2012, 157, 119-124. [CrossRef]

59. Patel, A.; Roy, P. The molecular biology of Bluetongue virus replication. Virus Res. 2014, 182, 5-20. [CrossRef]

60. Brookes, S.M.; Hyatt, A.D.; Eaton, B.T. Characterization of virus inclusion bodies in bluetongue virus-infected cells. J. Gen. Virol. 1993, 74, 525-530. [CrossRef]

61. Labadie, T.; Roy, P. A non-enveloped arbovirus released in lysosome-derived extracellular vesicles induces super-infection exclusion. PLoS Pathog. 2020, 16, e1009015. [CrossRef]

62. Gould, A.R.; Hyatt, A.D.; Eaton, B.T. Morphogenesis of a bluetongue virus variant with an amino acid alteration at a neutralization site in the outer coat protein, VP2. Virology 1988, 165, 23-32. [CrossRef]

63. Beaton, A.R.; Rodriguez, J.; Reddy, Y.K.; Roy, P. The membrane trafficking protein calpactin forms a complex with bluetongue virus protein NS3 and mediates virus release. Proc. Natl. Acad. Sci. USA 2002, 99, 13154-13159. [CrossRef]

64. Mertens, P.P.; Diprose, J.; Maan, S.; Singh, K.P.; Attoui, H.; Samuel, A.R. Bluetongue virus replication, molecular and structural biology. Vet. Ital. 2004, 40, 426-437.

65. Bhattacharya, B.; Noad, R.J.; Roy, P. Interaction between Bluetongue virus outer capsid protein VP2 and vimentin is necessary for virus egress. Virol. J. 2007, 15, 4-7.

66. Reber, A.; Kreienbrock, L.; Casati, S.; Chaignat, V.; Schwermer, H. Putative risk factors for infections with Toggenburg Orbivirus in goat herds in Southern Switzerland (Canton of Ticino). Vet. Microbiol. 2012, 160, 29-34. [CrossRef]

67. Zhang, X.; Boyce, M.; Bhattacharya, B.; Zhang, X.; Schein, S.; Roy, P.; Zhou, Z.H. Bluetongue virus coat protein VP2 contains sialic acid-binding domains, and VP5 resembles enveloped virus fusion proteins. Proc. Natl. Acad. Sci. USA 2010, 107, 6292-6297. [CrossRef]

68. Feenstra, F.; Pap, J.S.; van Rijn, P.A. Application of bluetongue Disabled Infectious Single Animal (DISA) vaccine for different serotypes by VP2 exchange or incorporation of chimeric VP2. Vaccine 2015, 33, 812-818. [CrossRef] 